\title{
The Inevitable Demise of the Implied Employment Contract
}

\author{
By Jonathan Fineman ${ }^{\dagger}$
}

In this article, Professor Fineman argues that courts' decision in the early 1980s to apply implied contract doctrine to employment relationships did not have the intended results. Employers immediately began restructuring their employment documents, and eventually found a way to essentially avoid liability through careful drafting of personnel documents. Professor Fineman further argues that the failure of contract law was inevitable based on the limitations of contract theory. Finally, Professor Fineman suggests a method to more successfully enforce workplace norms by looking to broader-based norms prevalent in the industry or applicable to the type of job position at issue.

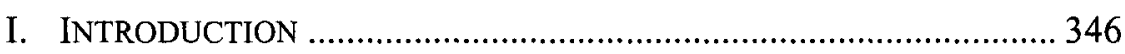

II. THE COMPLEX WORKPLACE-NORMS AND REGULATION..............350

A. The Construction and Effect of Workplace Norms ................. 351

B. Voluntary Adherence to Workplace Norms …………...............354

III. EARLY IMPLIED CONTRACT CASES IN CALIFORNIA …….................356

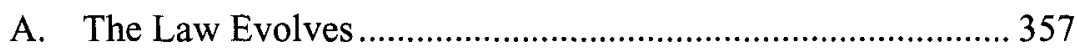

B. The California Supreme Court Speaks ....................................... 361

IV. EFFECTS OF THE IMPLIED CONTRACT DOCTRINE ………………....365

A. Actions and Reactions-the Employers Act .............................365

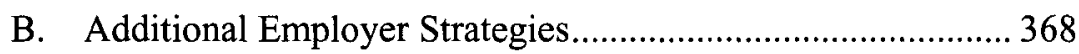

C. Employers Abandon the Field .................................................... 372

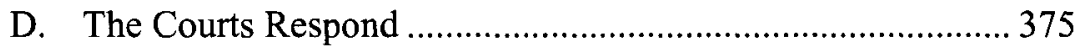

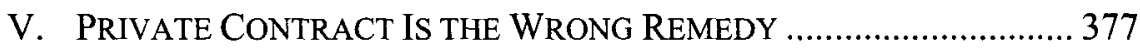

A. The Limits of Contract ….................................................... 378

1. The Power of One-Sided Drafting .................................... 378

\footnotetext{
† Assistant Professor, Florida A\&M University College of Law.

Email: jonathan.fineman@FAMU.edu. I would like to thank a number of people for their comments and suggestions, including professors Robert Ahdieh, Rachel Arnow-Richman, Roberto Corrada, Melissa Hart, Martin Katz, Risa Liebowitz, Stewart Macaulay, Elizabeth Mertz, Scott Moss, Nantiya Ruan, Teemu Ruskola, Robert Schapiro, Charles Shanor, Catherine Smith, and Katherine Stone. I would especially like to thank Professor Martha Fineman for her invaluable assistance and encouragement.
} 
2. At-Will Entrenchment

B. Contract and Discrimination-Two Different Approaches to the At-Will Rule .............................................................. 385

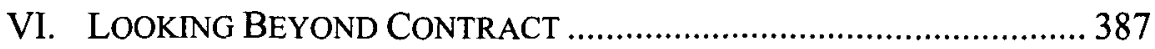

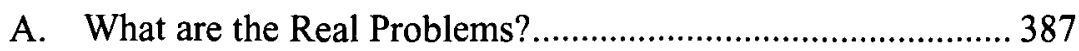

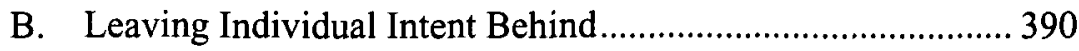

C. Moving Forward ............................................................. 391

1. Existing Proposals......................................................... 391

a. Covenant of Good Faith and Fair Dealing ………...... 392

b. Relational Contract ................................................... 395

2. Charting Future Directions: Aggregating Expectations and Norms to Govern the Employment Relationship ...... 399

a. Community Norms and Practices .............................. 399

b. Decision-Making ….................................................. 402

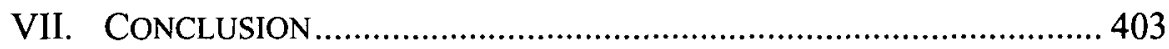

I.

INTRODUCTION

Can courts use implied contract doctrine to impose workplace norms of fairness on employers? Not long ago, the answer appeared to be 'yes,' but more recent case law has dimmed the once-bright prospect of using implied contract rights to redress and deter unfair terminations. Two prominent California cases, McLain v. Great American Insurance Cos. and Dore v. Arnold Worldwide, Inc., illustrate this contrast.

In McLain, a case tried in the mid-1980s, Robert McLain successfully sued his employer for wrongful termination in violation of an implied contract. ${ }^{1}$ Under the "at-will" employment system of American employment law, unless the decision to terminate McLain violated a specific statute or public policy, McLain's employer should have been able to terminate his employment for any reason or for no reason at all. Indeed, if McLain had brought his lawsuit ten years earlier, the court undoubtedly would have dismissed his claim for exactly this reason. However, beginning in the early 1980s, California (followed by many other states) began applying the general contract law principle of implied contract to employment cases. McLain's suit demonstrates the early promise, and success, of this effort to impose workplace norms of fairness on employers.

Under the at-will rule, courts presume that the employment relationship is at the independent will of both the employer and employee, and is

1. McLain v. Great Am. Ins. Cos., 256 Cal. Rptr. 863 (Ct. App. 1989). 
therefore terminable by either at any time for any reason. ${ }^{2}$ In addition to this presumption, McLain's employer, Great American Insurance Companies, relied upon an application form signed by McLain that read: "I agree that my employment and compensation can be terminated with or without cause, and with or without notice, at any time, at the option of either the Great American Insurance Company or myself."3

Despite the at-will rule and the application form, the jury found an implied contract between McLain and Great American whereby McLain would only be terminated for good cause. The following evidence supported the jury's decision: 1) Great American's personnel manual provided for progressive discipline before employees could be terminated for minor offenses or poor performance, and specifically listed the more serious offenses for which termination was an appropriate initial response; 2) Great American managers testified that the company had a policy and practice of firing only for cause; and 3) Great American told McLain that he would be a "permanent employee" after his initial probation period and informed him about long-term advancement opportunities. ${ }^{4}$ The Court of Appeal affirmed the jury's decision in $1989 . .^{5}$

McLain offers a textbook example of how the courts originally intended the implied contract remedy to be applied. Courts seemed troubled when employers informally expressed their intent to follow a particular policy of job security, such as progressive discipline or firing only for good cause, and then, after years of service by an employee who believed she would receive those protections, fired the employee in contravention of these expectations. ${ }^{6}$ In some such situations, courts have held that an employer's policies and practices, together with the employee's reasonable expectation that those policies would be followed, constituted an enforceable

2. The at-will doctrine was set forth by Horace G. Wood in his 1877 work, A TREATISE ON THE LAW OF MASTER AND SERVANT. In contrast, the common law of England presumed that employment was for a one-year term if the parties did not specify otherwise. Early American rules followed the English precedent until they were displaced by Wood's formulation of the employment at-will doctrine. See Jay M. Feinman, The Development of the Employment at Will Rule, 20 AM. J. LEGAL HIST. 118 (1976) (summarizing the English common law and tracing the development of the at-will doctrine).

3. McLain, 256 Cal. Rptr. at 865 .

4. $I d$. at 869 .

5. Id. at 867 .

6. See, e.g., Swanson v. Liquid Air Corp., 826 P.2d 664, 677 (Wash. 1992) (an employer cannot "make extensive promises as to working conditions-promises which directly benefit the employer in that the employees are likely to carry out their job satisfactorily with promises of assured working conditions--and then ignore those promises as illusory."); Small v. Springs Indus., Inc., 357 S.E.2d 452 (S.C. 1987) (as a matter of equity, employers cannot provide employees with policies and then choose to deviate from them whenever they see fit); Woolley v. Hoffman-LaRoche Inc., 491 A.2d 1257, 1271 (N.J. 1985) ("[i]t would be unfair to allow an employer to distribute a policy manual that makes the workforce believe that certain promises have been made and then to allow the employer to renege."); Leikvold $v$. Valley View Cmty. Hosp., 688 P.2d 170 (Ariz. 1984) (employer may not treat job protection provisions in official policies as illusory even with a disclaimer if employees are encouraged to rely on the protections). 
implied contract. $^{7}$

Twenty years later, the implied contract doctrine approach to employment law has been considerably curtailed. For example, in the 2006 case Dore v. Arnold Worldwide, Inc., plaintiff employee Brook Dore did not prevail in his breach of contract claim against his former employer, Arnold Worldwide, Inc. ${ }^{8}$ Like McClain, Dore had signed a piece of paper (this time an offer letter) acknowledging that his employment was at-will. Dore sought to establish an implied contract that he could only be fired for cause. Specifically, he offered evidence that he was given assurances in his hiring interviews that he "would play a critical role in growing the agency," that in filling the position the company "needed a long-term fix, not a Band-Aid," and that the company had a "family atmosphere." In addition, there was evidence of an informal policy or practice under which the previous holders of the position, as well as managers in general at the company who were long-term employees, were only fired for cause. ${ }^{10}$ Dore was also required to sign non-compete and non-disclosure agreements, suggesting that the parties intended a lengthy relationship. ${ }^{.1}$

The Court of Appeal determined that this evidence was sufficient to create an issue of material fact regarding the existence of an implied contract, and therefore reversed the trial court's summary judgment for Arnold Worldwide. ${ }^{12}$ However, the California Supreme Court disagreed and reversed, holding that the at-will provision in the offer letter constituted a written contract between the parties that could not be overcome by evidence of an implied contract requiring good cause. ${ }^{13}$ The court further held that any evidence of contrary representations, policies, or practices was barred by the parol evidence rule because the at-will language of the offer letter was unambiguous. ${ }^{14}$ Furthermore, even if the evidence were admissible, the court concluded that it could not reasonably have supported a belief that

7. An implied contract can arise from, among other sources: oral representations, terms in manuals and handbooks, the past practices of the employer or the mandates of the type of employment, including custom in the trade or industry. MARK ROTHSTEIN ET AL., EMPLOYMENT LAW 764 (3d ed. 2004).

8. Dore v. Arnold Worldwide, Inc., 139 P.3d 56 (Cal. 2006).

9. Dore v. Arnold Worldwide, Inc., No. B162235, 2004 WL 575161, at *6 (Cal. Ct. App. Mar. 24, 2004).

10. Id. at *7.

11. Id. at*6.

12. Id. at *7.

13. Dore, 139 P.3d at 59.

14. The common law parole evidence rule assumes the entire agreement between the parties is contained in a written contract and prohibits introduction of evidence outside the four corners of the contract when its terms are clear. In California, the rule is codified in section 1856 of the Civil Procedure Code, which states: "Terms set forth in a writing intended by the parties as a final expression of their agreement with respect to such terms as are included therein may not be contradicted by evidence of any prior agreement or of a contemporaneous oral agreement." Cal. Civ. Proc. Code $\S 1856$ (a) (West 2008). 
Arnold Worldwide did not mean what it said in the offer letter. ${ }^{15}$

What explains why McLain and Dore fared so differently with their claims? Certainly their cases raise the same basic questions of employment law and identical concerns about fundamental fairness and equity in the employment context. This Article will answer this question by discussing the evolution of the implied contract doctrine in employment cases and the practical and legal implications of the implied contract doctrine as a device to address employer opportunism.

Although courts did not use the rhetoric of "norms" popular in academic discourse today, ${ }^{16}$ their actions were in fact an attempt to enforce workplace norms through contract law. Over the last century, employers developed and largely followed a system of job protection policies, often including policies of progressive discipline and termination for good cause. By following these policies, employers increase worker loyalty and productivity, decrease costs, and obtain other tangible benefits. Courts originally applied implied contract doctrine to prevent employer opportunism, whereby employers would receive the benefits of representing that they followed job protection policies, but would then terminate the employee in violation of those policies after years of loyal service. ${ }^{17}$

What happened when courts began giving job-security workplace norms the force of law? I argue that the results were not what the courts intended. After the first few cases were decided, there was an immediate reaction on the part of employers who did not want their voluntary policies to become enforceable contracts. Employers began restructuring their employment documents, policies and practices to avoid liability. Through a process of trial and error, employers eventually were able to find a way to immunize themselves against implied contract claims. With careful drafting of personnel documents, employers today have little fear of implied contract lawsuits. As a result, many employees are arguably now worse off than they were in the 1970 s. Not only are implied contract claims nearly impossible to win, most employees no longer have the benefit of formal job protections that were abandoned to avoid liability.

I argue that this failure of implied contract doctrine law to provide enduring job protections was inevitable. Although courts seeking to enforce

15. Dore, 139 P.3d at 60-61.

16. See, e.g., Edward B. Rock \& Michael L. Wachter, The Enforceability of Norms and the Employment Relationship, 144 U. PA. L. REV. 1913 (1996) (arguing that courts should not enforce workplace norms unless the parties expressly agree to enforce them).

17. See, e.g., Pugh v. See's Candies, Inc., 171 Cal. Rptr. 917 (Ct. App. 1981). The prevalent theory is that a unilateral contract is formed when an employer issues statements limiting its prerogatives, such as the application of the at-will rule, and the employee subsequently begins or continues work. The language must be clear enough so that an employee can reasonably believe that he or she has been offered employment under its terms and the offer must be disseminated to the employee. There is no further consideration required, and hence no mutuality of obligation is required. See ROTHSTEIN, ET AL., supra note 7, at 750; see also discussion infra Part III.A. 
implied employment contracts have some flexibility to interpret contract principles to reach a "fair" result, this judicial flexibility only reaches so far. When faced with a clear expression of employer intent that the employment relationship be at-will, there is only so much a court can do. While courts can use public policy to achieve results not achievable through traditional contract principles, this seems unlikely in the employment context. Those public policy decisions consistently favor the entrenched at-will policy that defines the American workplace. In this respect, the implied contract remedy is fundamentally different from other "exceptions" to the at-will rule. Unlike antidiscrimination statutes that impose upon the parties certain unavoidable obligations based on public policy, implied contract doctrine does not import external values into the employment relationship.

Conceptualizing the employment relationship as one of private contract, the terms of which as a practical matter are established by employers, means that we will always end up with employment contracts that benefit employers. As long as individual employers are able to define the scope of their own obligations, efforts to instill more structured, effective and binding workplace norms through the doctrine of implied contracts will be unsuccessful. We must look beyond traditional contract law if we wish to enforce more equitable workplace norms.

Finally, I build on some existing proposals and suggest directions for future work in this area that are resistant to traditional contract law's reliance on the individual parties' intent. To successfully enforce workplace norms, we must remove employers' unilateral ability to structure the employment relationship to avoid liability. I suggest looking beyond the relationship between the particular employee and employer to broader-based norms prevalent in the industry, applicable to the type of job position at issue, or generally accepted on a society-wide basis. I argue that employers should not be able to opt out of the norms followed by similarly-situated employers dealing with similarly-situated employees. This aggregate norms approach allows greater flexibility than contract obligations for employers, while still protecting reasonable employee expectations. Ironically, as the conclusion argues, looking beyond the dictates of private contract in this way may actually set the stage for more equitable bargaining and negotiation between employers and employees.

II.

THE COMPLEX WORKPLACE-NORMS AND REGULATION

The basic presumption of employment since the late 19th century has been the "at-will" rule. The term at-will describes a conceptual approach to employment whereby, unless there are specific terms to the contrary, each 
party is unilaterally and equally able to walk away from the relationship. ${ }^{18}$ Because each party is able to terminate the relationship at any time, each may also unilaterally change the terms of the relationship at any time. An employer is entitled to make unilateral changes because this would be the logical equivalent of firing the employee and then immediately offering her the same position under different terms. ${ }^{19}$ The position of an at-will employee is one of inherent instability; her employer may terminate her for a reason wholly unrelated to her job performance or merit. ${ }^{20}$

\section{A. The Construction and Effect of Workplace Norms}

The at-will rule does not alone govern the employment relationship, which is recognized as one of the most complex and important relationships in modern society. ${ }^{21}$ State and federal legislatures have adopted statutes that limit employers' discretion in some respects. For example, concern over the welfare of employees motivated the establishment of standards applicable to most workplaces with respect to minimum wages and occupational safety and health. ${ }^{22}$ Other employee protection statutes are designed

18. In recent years there has been a great deal of academic criticism directed at the at-will rule, particularly towards the premise of egalitarianism upon which it is based. Robert C. Bird, Rethinking Wrongful Discharge: A Continuum Approach, 73 U. CIN. L. REV. 517,517 \& n.1 (2004) (noting that over 200 scholarly articles critical of the at-will rule have been published since 1985). In an at-will world, if either party is dissatisfied with the employment relationship, whether based on the performance or conduct of the other or on mere whim, the remedy is the termination of the relationship. But the implications of that termination are decidedly different for a typical employee and a typical employer. Commentators have discussed in detail the unequal nature of the respective positions of employers and employees, asserting that the at-will rule obscures and enables the exploitation of vulnerable employees. Frank J. Cavico, Employment At Will and Public Policy, 25 AKRON L. REV. 497, 502 (1992) ("Given the considerable disparity in economic power and bargaining positions between employers and employees, particularly large corporate employers, and the employer's chiefly unchecked control over the terms and conditions of the employment relation, abuses in the treatment of employees naturally arise.").

19. For example, in California, an employer may unilaterally modify the terms of the employment relationship even in the rare instance where the terms are memorialized in a written contract between the parties. The rationale for this ability is explained in Digiacinto v. Ameriko-Omserv Corp., 69 Cal. Rptr. 2d 300 (Ct. App. 1997). In Digiacinto, the parties entered into a written employment agreement providing that Victor Digiacinto would receive \$23.97 per hour to work as a supervisor. Id. at 301 . The contract also specified that his employment could be terminated at any time with or without cause. Id. Five months later, he was informed that as a cost cutting measure, his pay would be reduced to $\$ 18.00$ per hour. Id. at 301-02 The court held that an employer may unilaterally change its compensation agreement with an employee without breaching the employment contract. Id. at 304-06. According to the court, "with respect to an at-will employee, the employer can terminate the old contract and make an offer for a unilateral contract under new terms." Id. at 304. As a matter of law, the court found that "an at-will employee who continues in the employ of the employer after the employer has given notice of changed terms or conditions of employment has accepted the changed terms and conditions." Id. at 30405.

20. See Feinman, supra note 2.

21. Developments like civil service protection for public employees and the ascendancy of organized labor after the National Labor Relations Act was enacted in 1935 meant that "just cause" requirements applied to much of the labor force, perhaps setting the stage for reconsideration of the at-will rule in private employment contexts in the latter half of the century.

22. See, e.g., Fair Labor Standards Act of 1938, 29 U.S.C.A. $\S ~ 201-219$ (West 2008); Occupa- 
to achieve a transcending policy objective, such as preventing discrimination based on gender, race, religion, disability, or age. ${ }^{23}$

In addition, most states constrain employer actions that would adversely affect public policies or general laws. ${ }^{24}$ For example, in almost all jurisdictions it is unlawful to fire an employee for refusal to perform an unlawful act. ${ }^{25}$ Most states protect whistle-blowers from retaliation, particularly when the matter involves an issue of public concern that is brought to the attention of authorities. ${ }^{26}$ It is important to note that technically the at-will rule is not displaced by these exceptions. Rather, public policy exceptions merely identify certain motivations on the part of the employer that generate a wrongful discharge claim on the part of the employee. ${ }^{27} \mathrm{Al}-$ though these exceptions provide some remedy, the at-will rule prevails, and in most circumstances, the legal relationship between employers and employees remains one of private contract unmediated by public policy. ${ }^{28}$

tional Safety and Health Act of 1970, 29 U.S.C.A. $\$ \S 651-678$ (West 2008).

23. See, e.g., Age Discrimination in Employment Act of 1967, 29 U.S.C.A. $\$ \S 621-634$ (West 2008); Americans with Disabilities Act of 1990, 29 U.S.C.A. $\$ \S 12101-12213$ (West 2008); Title VII of the Civil Rights Act of 1964, 42 U.S.C.A. $\$ \S 2000 \mathrm{e}$ to $2000 \mathrm{e}-17$ (West 2008).

24. Many jurisdictions follow rules broadly prohibiting terminations that violate important public policies. See, e.g., Palmateer v. Int'l Harvester Co., 421 N.E.2d 876 (Ill. 1981); Pierce v. Ortho Pharma. Corp., 417 A.2d 505 (N.J. 1980); Tameny v. Atl. Richfield Co., 610 P.2d 1330 (Cal. 1980); Geary v. U.S. Steel Corp., 319 A.2d 174 (Pa. 1974).

25. The earliest case on this point, in which an employee was fired for refusing to commit perjury at a legislative hearing, is Petermann v. International Brotherhood of Teamsters, Local 396, 344 P.2d 25 (Cal. Dist. Ct. App. 1959). See also Scott A. Moss, Where There's At-Will, There Are Many Ways: Redressing the Increasing Incoherence of Employment at Will, 67 U. Pitt. L. Rev 295 (2005) [hereinafter Moss, At-Will] (discussing variation among states in recognizing public policy and other common law exceptions to employment at will).

26. There are wide variations among state whistleblower protections. One area of dispute is whether internal whistleblowing situations are covered in the same way as external cases. If an employee has only complained to internal management and not to public authorities, a court may find that this reflects nothing more than an internal disagreement between the employee and decisionmakers within the company, and conclude that the circumstances surrounding an employee's termination do not constitute a wrongful discharge. Compare Belline v. K-Mart Corp., 940 F.2d 184 (7th Cir. 1999) (employee who alleged that he was fired in retaliation for reporting suspicious behavior by his supervisor to management had a cause of action under Illinois law for retaliatory discharge) with House v. CarterWallace, Inc., 556 A.2d 353 (N.J. Super. Ct. App. Div. 1989) (employee's internal objections to company conduct did not provide grounds for wrongful termination claim based on retaliatory discharge) Federal legislation on this point includes the Sarbanes-Oxley Act of 2002, 18 U.S.C.A $\S 1514$ A (West 2008), 18 U.S.C.A. $\S 287$ (West 2008) and the False Claims Act, 31 U.S.C.A. $\S \S 3729-3730$ (West 2008). Federal employees have additional protections under the Civil Service Reform Act and the Whistleblower Protection Act.

27. ROTHSTEIN ET AL., supra note 7, at $\mathbf{7 7 4 .}$

28. It is curious that the law largely treats employment as a matter of private concern, considering the significant effects employment decisions have on employees and society as a whole. Studies have shown that employees who are fired from their jobs have an increased likelihood of depression, substance abuse, illness and suicide. There is also evidence that spouses of fired employees also suffer similar effects. In addition, unemployment is linked to increased levels of divorce, child abuse and infant mortality. Unemployment also contributes to poverty and crime. For every $1 \%$ increase in unemployment, there are increases of $5.7 \%$ in homicides, $4.1 \%$ in suicides and $1.9 \%$ in heart, liver and stressrelated deaths. Robert C. Bird, Employment as a Relational Contract, 8 U. PA. J. LAB. \& EMP. LAW 
Notwithstanding the legalities, employers established their own, often informal, rules and practices in the absence of comprehensive state regulation. For example, beginning in the late 19th century many American employers began instituting hierarchical job ladders, specific job classification systems, seniority systems, and employee retention policies ${ }^{29}$ as part of a nationwide restructuring of the workforce into "internal labor markets." 30 Collectively, these practices provide a structure for employee advancement and some degree of job stability.

Although these structural policies were constructed in the shadow of the at-will rule, in practice they have often operated to contain the unbridled discretion of employers under the law. Of particular importance to employees, many of these workplace practices and procedures take the form of job security protections. Common examples include: 1) the employer may only fire an employee when there is good cause to do so; 2) the employer shall apply progressive discipline practices that provide warning and other interim steps before termination; 3) the employer will provide fair investigation and hearing procedures for allegations of employee misconduct; and 4) the employer will provide internal placement opportunities for employees terminated for reasons unrelated to performance.

In addition to specific representations, established practices within a workplace may structure and shape an employer's negotiations with potential employees. After all, new employees will join an existing workforce with established procedures and processes. If they are treated better than current employees it will cause dissention. If they are treated worse, they are likely not to join or to leave when they realize their disadvantage.

The promise of job security provided by such practices is attractive to potential employees, and is potentially as important as more traditional wage or benefit provisions. ${ }^{31}$ Employers communicate job security policies in a number of ways. The policies may be general in nature, set out in employee handbooks or other personnel documents. In addition, acceptance letters may include more specific, individualized representations. Jobsecurity policies may also be expressed orally. Further, general practices may be well established and well known even if they are unwritten.

Although these protective practices and policies are directed at employees, they also benefit employers. ${ }^{32}$ Otherwise, one suspects that they

$149,162(2005)$.

29. Katherine V. W. StONe, From Widgets to Digits: EMPLOYMENT REgulation for the CHANGING WORKPLACE 46-48 (2004).

30. Id. at 48,52 .

31. Id. at 53-54.

32. In fact, the Michigan Supreme Court has found that employers benefit from creating the impression that job protection policies are practiced, even if employees are not aware of any concrete or specific written protections. Toussaint v. Blue Cross \& Blue Shield, 292 N.W.2d 880, 891-93 (Mich. 1980). 
would not be fashioned and implemented in the first place. Indeed, the management experts who first devised these practices explicitly described their purposes and benefits. The policies were designed to improve employee morale, foster employee loyalty and motivation, and encourage training and sharing of knowledge. ${ }^{33}$ Internal labor markets were touted as reducing employee turnover, saving the employer recruitment, screening and training costs, and increasing the value of the workforce by facilitating training. ${ }^{34}$

Studies show that employers who have loyal, committed employees receive significant competitive advantages over those who do not. The direct benefits of a committed workforce include higher employee retention, attendance, effort, and job performance. ${ }^{35}$ Committed employees also provide their employers with indirect rewards such as improved customer service, sales, and cost control. ${ }^{36}$

It is important to note, however, that employers create these protective policies and practices against the backdrop of the autonomy that the at-will rule provides all employers. The at-will rule is more than a legal presumption; it also has served for generations as the background understanding for the entire employment relationship. ${ }^{37}$ Employers have relied on the at-will right to terminate employees' employment, regardless of any representations about job protection policies to the contrary made in manuals or orally. When it suits their needs, employers break the rules and norms they themselves established and revert to their at-will prerogative.

\section{B. Voluntary Adherence to Workplace Norms}

Employers developed internal labor market practices in part to decrease the likelihood that employees would unionize or otherwise engage in

33. STONE, supra note 29 , at $47-48$.

34. Id. at 53 .

35. Bird, supra note 28, at 181-82; Sheri Bridges \& J. Kline Harrison, Employee Perceptions of Stakeholder Focus and Commitment to the Organization, 15 J. MANAGERIAL ISSUES 498, 500 (2003); Tim Davis \& Michael J. Landa, Creating Shareholder Value: Impossible Dream or Achievable Business Objective?, 25 THE CANADIAN MANAGER 23, 24 (2000).

36. Bird, supra note 28 , at 181-82. These benefits explain why employers were eager to keep their handbooks and other representations of beneficial policies even when their existence resulted in findings of implied contracts. See discussion supra Parts IV.A-B.

37. The only state to change the at-will rule by statute is Montana. Mont. Code Ann. $\$ 39-2-04$ (2007). Montana's Wrongful Discharge from Employment Act created a cause of action for employees who, after a probationary period, were fired without good cause. Id. See also the similar provisions in the Model Employment Termination Act of 1991, $\S 3(\mathrm{a}), 4(\mathrm{c})$, which has not been adopted by any state. However, the Montana statute significantly limits the remedies available to plaintiffs and it has been argued that employers in Montana are actually better off than their counterparts elsewhere. Bradley $T$. Ewing, Charles M. North \& Beck A. Taylor, The Employment Effects of a "Good Cause" Discharge Standard in Montana, 59 IND. \& LAB. REL. REV., 17, 21 (2005) (discussing the statute's trade off between worker protections and limitations on traditional common law causes of actions and damages). In fact, Montana employers supported the statute when it was passed. Id. 
collective activity. After the 1930 s, labor unions actively policed the rules of internal labor markets in unionized workplaces. ${ }^{38}$

Outside of the union context, job security practices and standards do not have the force of law in any formal sense. However, they may establish employee aspirations and expectations that far exceed legally-mandated standards. Given that these internal labor market structures serve important institutional functions, employees may reasonably conclude that they help shape the terms of the employment contract. Therefore, it is not entirely accurate to say that individual employers are free to structure the employment relationship in any way that they see fit.

Employers must at least pay lip service to general workplace norms if they are to attract and retain employees. In turn, employees expect employers to act within the confines of those same norms, even though the employer may have no legal obligation to do so. ${ }^{39}$ In addition, these expectations shape employee behavior, as employees conform to their understanding of the workplace norms and practices the employer endorses ${ }^{40}$ In fact, in practice it appears that employers widely follow many basic workplace norms, including terminating employees for good cause. ${ }^{41}$

Employers benefit from progressive discipline, "good cause," and other job security policies because they help create a productive, loyal workforce that believes the employer acts fairly. ${ }^{42}$ However, any illusion of symmetry is misleading given the unequal ability of employers and employees to ignore or frustrate a policy or standard. Employers voluntarily establishing job security policies, while they may well embrace the benefits those policies confer, do not necessarily want their handbooks, policies, and practices to dictate every action they take. They may want to retain the benefits of the at-will rule and, with it, the ability to alter or even abandon the policies in a specific case or type of case. ${ }^{43}$

Employers have reason to resist giving these job security policies the force of law. Doing so could open the door to frivolous lawsuits. ${ }^{44} \mathrm{Em}-$

38. STONE, supra note 29 , at 62 .

39. Judge Richard Posner indicated that one function of an employment handbook was to convey useful information to employees. Workman v. United Parcel Servs., Inc., 234 F.3d 998, 1001 (7th Cir. 2000). In addition, even if not legally binding, a handbook's promises "plac[ed] the employer under a moral obligation, or more crassly gives him a reputational incentive, to honor those promises." Id. This analysis is based on the idea that workplace norms are self-enforcing, even if they are not legally binding. See also Edward B. Rock \& Michael L. Wachter, The Enforceability of Norms and the Employment Relationship, 144 U. PA. L. REV. 1913 (1996).

40. Rock \& Wachter, supra note 39.

41. See Jesse Rudy, What They Don't Know Won't Hurt Them: Defending Employment-At-Will in Light of Findings that Employees Believe they Possess Just Cause Protection, 23 BERKELEY J. EMP. \& LAB. L. 307, 342-43 (2002) (citing estimates that an employee has a less than one percent probability of being disciplined or dismissed for a reason that would violate a union just cause standard).

42. See STONE, supra note 29.

43. See discussion infra Part VI.

44. See discussion infra Part VI. 
ployers may also fear that juries or judges do not possess the necessary expertise or experience to determine if a personnel decision was warranted. ${ }^{45}$ In addition, the employers may fear that juries in particular will be biased in favor of employees. Such employer concerns may be legitimate. But employee concerns and fears should also be part of the equation, and an equitable balance must consider the concerns and expectations of both employees and employers.

Courts have recognized that employer opportunism is a problem. Employers knew that their job protection policies are not legally binding, and employers therefore choose to ignore them in particular circumstances. ${ }^{46}$ Employers should not be able to foster employee expectations about job security, and then act in contravention of those expectations after reaping increased employee productivity and loyalty.

III.

\section{EARLY IMPLIED CONTRACT CASES IN CALIFORNIA}

The development of the law in California illustrates how courts were initially motivated to implement the implied contract doctrine by the sense of fairness they perceived to be underlying employee claims based on employer representations. The development of the case law in California presents the opportunity to study the evolution of the implied contract doctrine over time.

California is the logical jurisdiction for this type of case study for a number of reasons. California was a trendsetter state in the area of implied contract (as in many other doctrinal areas), being one of the first to allow such claims in the employment context. ${ }^{47}$ Second, partly because of its trendsetter role, California is recognized as a particularly "employeefriendly" state in its statutory and common-law employment rules. ${ }^{48}$ Indeed, California courts have long resisted employers' attempts to use disclaimers to avoid implied contractual liability. In this respect, California is more liberal than other states that quickly rejected any such strategy. Third, the implied contract doctrine has been extensively developed through litigation in California, which has a comparatively large number of reported decisions. As a result of this extensive litigation, we are able to trace the development of employer responses to the implied contract doctrine.

In addition, and perhaps most importantly, implied contract litigation

45. It is true that courts and juries generally are not experts in the workplace practices prevalent in any specific industry. Accordingly, this Article suggests mediation or arbitration as an alternative that allows for decisionmaking by more knowledgeable people. See discussion infra Part VI.

46. See discussion infra Part V.

47. See Petermann v. Int'l Bhd. of Teamsters, Local 396, 344 P.2d 25 (Cal. Dist. Ct. App. 1959).

48. California courts have responded to issues of fairness and equity. See discussion at notes 5256 supra. 
has reached an "end game" in California. Through trial and error, employers eventually came up with a court-approved strategy for effectively avoiding liability in implied contract claims. ${ }^{49}$ The ensuing discussion of the limits of implied contract under California law applies equally well in any state that recognizes such claims, even if there are some state-based distinctions in how the struggle has played out.

\section{A. The Law Evolves}

California courts have long récognized some overlap between implied contract principles and employment law. Early decisions primarily dealt with employees' right to receive promised benefits that they had already earned. For example, in a 1955 case, the Court of Appeal held that an employer's policy to pay severance benefits could be enforced as a contract. ${ }^{50}$ This type of implied contract remedy was a relatively small step for the courts. They simply had to enforce the traditional payment-for-work bargain in situations where the employer attempted to avoid payment for work already performed.

The situation of "implied contract" discussed in this Article refers to a larger, more modern conceptual leap for the courts in which they hold employers to their representations and promises about job security that are not part of the traditional compensation bargain. Historically, employers would otherwise be free to change or discard these conditions at any time. The most common examples of modern implied contract claims are: 1) an implied agreement that employees cannot be fired absent good cause; and 2) an implied agreement that employers will follow some form of progressive discipline or investigative procedures before terminating an employee.

California is an at-will state, ${ }^{51}$ but both the courts and the legislature have created exceptions to the rule, such as public policy claims and antidiscrimination statutes. In the early $1980 \mathrm{~s}$, these exceptions emboldened the courts to address the unfairness perceived when employers do not follow their own policies. ${ }^{52}$ In doing so, California courts were motivated by a sense of fairness. ${ }^{53}$ As described in Part II, supra, employers receive nu-

49. See Dore v. Amold Worldwide, Inc., 139 P.3d 56 (Cal. 2006).

50. Chinn v. China Nat'l Aviation Corp., 291 P.2d 91, $91-92$ (Cal. Dist. Ct. App. 1955); see also Newberger v. Rifkind, 104 Cal. Rptr. 663, 667 (Ct. App. 1972) (implied contract for stock option agreement); Hunter v. Sparling, 197 P.2d 807, 813-14 (Cal. Dist. Ct. App. 1948) (implied contract to pay pension benefits inferred from personnel policies).

51. California's at-will rule is codified in Labor Code section 2922, which provides in pertinent part: "An employment, having no specified term, may be terminated at the will of either party on notice to the other." Cal. Lab. Code $\$ 2922$ (West 2008).

52. See Pugh v. See's Candies, Inc., 171 Cal. Rptr. 917, 926-28 (Ct. App. 1981); Cleary v. Am. Airlines, Inc., 168 Cal. Rptr. 722 (Ct. App. 1980).

53. The same fairness concerns can be found even where the employee signed an express contract providing for employment at-will. See, e.g., Wagner v. Glendale Adventist Med. Ctr., 265 Cal. Rptr. 412, 418 (Ct. App. 1989) ("When one party has, through oral representations and conduct or custom, 
merous benefits from fostering the belief that employees can only be fired for good cause. It would not be fair to allow employers to receive these benefits and then fire employees without cause after years of loyal service. $^{54}$

The California Supreme Court has acknowledged the "widespread support among scholars and practitioners in the field of human resources management for the position that employee discipline should be governed by basic principles of due process." 55 The court specifically noted four benefits that employers receive from job security protections: "1) a more productive, responsible work force committed to the enterprise; 2) avoidance of union interference; 3 ) avoidance of litigation based on statutory civil rights laws or common law wrongful termination claims; and 4) the provision of incentives to retain current employees and attract new ones." Employees, in turn, may rely on their beliefs about job security in deciding whether to accept employment or forego other job opportunities.

In the 1980 case Cleary $v$ American Airlines, ${ }^{57}$ California courts first addressed the issue of what to do when an employer violates its own job protection policies by terminating an employee under the at-will rule. Cleary is often overlooked as the first such case in favor of the more famous decision Pugh v. See's Candies, ${ }^{58}$ reported four months later. This is probably because the Cleary Court characterized the claim as one of breach of good faith and fair dealing, rather than implied contract, per se. This approach was later rejected, as discussed infra.

Regardless of the framing of the claim, however, Cleary is an instructive case for examining what motivated courts to seek a remedy for opportunistic employer conduct. Cleary alleged that he was discharged after eighteen years of employment with American Airlines because he was involved in union organizing. ${ }^{59}$ He further alleged that American failed to comply with its self-adopted regulations, which allowed employees to protest their discharge though a "fair, impartial and objective hearing" and a "fair, impartial and objective review" of that hearing by a review board. ${ }^{60}$

\footnotetext{
subsequently behaved in a manner antithetical to one or more terms of an express written contract, he or she has induced the other party to rely on the representations and conduct or custom. In that circumstance, it would be equally inequitable to deny the relying party the benefit of the other party's apparent modification of the written contract.").

54. Other jurisdictions have based their implied contract remedies on the same fairness considerations. See, e.g., Swanson v. Liquid Air Corp., 826 P.2d 664, 677 (Wash. 1992); Small v. Springs Indus., Inc., 357 S.E.2d 452 (S.C. 1987); Woolley v. Hoffmann-La Roche Inc., 491 A.2d 1257, 1271 (N.J. 1985); Leikvold v. Valley View Cmty. Hosp., 688 P.2d 170 (Ariz. 1984).

55. Scott v. Pac. Gas \& Elec. Co., 904 P.2d 834, 843 (Cal. 1995).

56. Id.

57. Cleary, 168 Cal. Rptr. 722.

58. 171 Cal. Rptr. 917 (Ct. App. 1981).

59. Cleary, 168 Cal. Rptr. at 724.

60. Id.
} 
The trial court dismissed the case for failure to state a claim based upon the employer's invocation of the at-will rule. The Court of Appeal reversed, holding that the plaintiff's longevity at the company, together with the company's adoption of regulations that detailed a specific procedure to be followed before termination, "compels the conclusion that this employer had recognized its responsibility to engage in good faith and fair dealing rather than in arbitrary conduct with respect to all of its employees." 61 These two factors were considered to "operate as a form of estoppel, precluding any discharge of such an employee by the employer without good cause."62

The Court of Appeal in Cleary was concerned with the possible harsh consequences that would result from allowing the employer to rely on the at-will rule. ${ }^{63}$ The court focused on the unequal position of the parties, with the employer enjoying more options and choices in a practical sense:

The absolute power conferred ... on an employer to discharge the at-will employee without cause is founded on the contractual concept of mutuality of obligation. The reasoning is that, since an employee may terminate the employment relationship when he wishes to do so, the employer is also entitled to terminate the relationship at his pleasure. However, when viewed in the context of present-day economic reality and the joint, reasonable expectations of employers and their employees, the freedom bestowed by the rule of law on the employee may indeed be fictional. ${ }^{64}$

The court explicitly recognized the policy interests at stake, noting the continuing trend toward recognition of certain implied contractual rights to job security by the courts and the Legislature. The court deemed these rights necessary to ensure social stability. ${ }^{65}$ The court quoted with approval an academic critique of the at-will rule, ${ }^{66}$ which advocated implied contract rights for employees. The court found particularly persuasive the article's assertion that in situations of "conflict between an employee's right to job security and an employer's right to fire," the resolution should reflect a "judicial balancing of the competing equities." 67

A mere four months later, the Court of Appeal recast Cleary's approach and its choice of remedies for a different district in Pugh v. See's Candies. ${ }^{68}$ The plaintiff in $P$ ugh shared some of the characteristics found compelling for the plaintiff in Cleary. He was terminated after 32 years of exemplary service with See's Candies because he objected to a "sweetheart

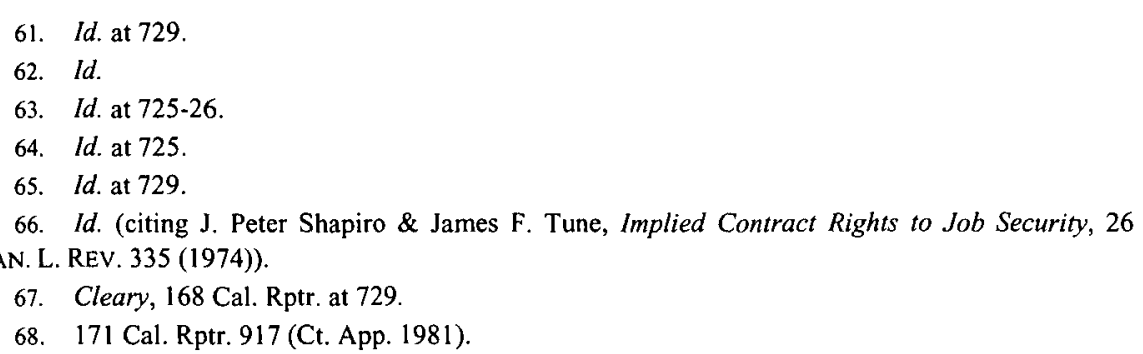


deal" between his employer and a labor union. ${ }^{69}$ See's had a "practice of not terminating administrative personnel except for good cause," and the president of the company frequently told plaintiff that if he was loyal to See's and did a good job, his "future [was] secure."70

Like in Cleary, the Pugh court noted the general trend toward limiting employers' right to terminate employees under any circumstances. Rather than build on the good faith and fair dealing language of Cleary, however, the court developed another limitation. There could be an agreement, ${ }^{71}$ express or implied, that employment will continue indefinitely unless there is some event giving rise to the employer's dissatisfaction with the employee's services or other cause for termination. ${ }^{72}$ The court outlined factors to consider in determining whether such a contract exists, which have remained relatively unchanged: The personnel policies or practices of the employer were important, as was the employee's longevity of service, and any actions or communications by the employer reflecting assurances of continued employment. Also relevant were the practices of the industry in which the employee is engaged. ${ }^{73}$

Pugh, like Cleary, reflected the willingness of the court to take a liberal view of contract law to afford employees a remedy under certain circumstances. ${ }^{74}$ The employer challenges to the finding of an implied contract doctrine were based on the traditional doctrine of mutuality of obligation, which requires shared consideration. The court rejected the argument that the employer was not required to provide reasons for termination unless equivalent limits were placed upon the employee for quitting. The court held that if the basic requirement of consideration was met, there would be no additional requirement, such as some form of equivalence in the values exchanged or mutuality of the obligations imposed. ${ }^{75}$

69. Id. at $918-20$.

70. Id. at 919 .

71. The court discussed and rejected challenges to the formation of an implied contract based on the traditional contract doctrines of mutuality of obligation and independent consideration, holding that an employee's continuing services are sufficient consideration to support an agreement for indefinite employment. $1 d$. at $924-25$.

72. Id. Guz $\mathbf{v}$. Bechtel Nat'l, Inc. teaches that longevity of service, promotions, positive performance reviews, salary increases and similar indicia of positive performance do not by themselves imply an employer's contractual intent to give up its at-will rights-these are only "consequences of a wellfunctioning employment relationship" and are not alone indicative of employer's intent. 8 P.3d 1089, 1104-06 (Cal. 2000).

73. Pugh, 171 Cal. Rptr. at 925-26. The last factor, industry custom, is referenced in the caselaw but does not seem to have gained much traction in practice. Few plaintiffs argue industry custom, and no published decision has relied on this factor.

74. The plaintiff in Pugh lost on remand. The appellate court indicated that the trial court should not interfere with subjective management decision-making, and the jury returned a verdict for the defendant after hearing evidence that the plaintiff was "rude, belligerent, and uncooperative," as well as "disrespectful ... disloyal ... and uncooperative." Pugh v. See's Candies, Inc., 250 Cal. Rptr. 195, 203 (Ct. App. 1988).

75. Pugh, 171 Cal. Rptr. at 924-25. 
Importantly, in setting out on the implied contract path, the Pugh court distanced itself from Cleary's good faith and fair dealing remedy. In Pugh, the court determined that it need not go so far as to recognize a general duty of good faith and fair dealing limiting employers' ability to discharge longserving employees. The court in Pugh interpreted Cleary's holding limiting the employer's authority to fire as based on two independent grounds. The first ground was the breach of the duty of good faith and fair dealing created by the plaintiff's long tenure. The second was the employer's adoption of specific policies and practices for dealing with employee grievances. ${ }^{76}$

Even though Cleary clearly described both grounds in terms of the duty of good faith and fair dealing, Pugh separated out the second and held that attention to the established grievance procedure was "equally explicable in traditional contract terms." The court found that the employer's conduct in this regard gave rise to an implied promise that it would not act arbitrarily in dealing with its employees. ${ }^{77}$ By pulling back on the duty of good faith and fair dealing and recasting Cleary, the Pugh court essentially constrained future plaintiffs to remedies founded on implied contract.

\section{B. The California Supreme Court Speaks}

Seven years later, in 1988, the California Supreme Court for the first time entered the scene and examined the issue of implied contract claims in the employment context. Basically, it adopted the Pugh, rather than the Cleary approach, separating tort from contract and favoring the latter. ${ }^{78}$ The plaintiff in Foley v. Interactive Data Corp. ${ }^{79}$ was terminated after seven years of employment. ${ }^{80}$ The plaintiff had recently informed management that his immediate supervisor was under investigation by the Federal $\mathrm{Bu}$ reau of Investigation for embezzling from his former employer. Apparently, Interactive Data believed that the plaintiff was trying to oust his supervisor. He pursued both an implied contract claim under Pugh and a good faith and fair dealing claim under Cleary. ${ }^{81}$ The plaintiff argued that Interactive Data maintained written policies setting forth express grounds for discharge. There was also a mandatory seven-step pre-termination procedure. He alleged that based on these policies, he reasonably believed that

76. Id. at $926-27$.

77. Id.

78. In making this distinction, the California Supreme Court may have been attempting to limit recoveries in general by removing the possibility of tort-based recovery and relegating the employee to a contract remedy. The size of the awards being given under the combined theories in Cleary and Pugh were reported by Jung and Harkness to average $\$ 220,000$ in the late 1980 s. David Jung \& Richard Harkness, The Facts of Wrongful Discharge, 4 LAB. LAW. 257, 261 (1988).

79. 765 P.2d 373 (Cal. 1988).

80. Id. at 375-76. The court dismissed plaintiff's additional claim for wrongful discharge in violation of public policy because it found that the only interests at stake were private, rather than public, in nature. Id. at 380 .

81. Id. at 374 . 
he could not be fired without good cause. ${ }^{82}$

The California Supreme Court embraced the implied contract approach. Furthermore, the court was explicit in applying the modern perception of contract to these cases. Finding that Pugh correctly applied general and basic contract principles in the employment context, ${ }^{83}$ the court acknowledged that previously, special rules had been applied to employment contracts. In the past, promises of employment security were not enforced without evidence of independent consideration and an express agreement.

Noting that these rules were created in the late 19th century, a time when courts were generally reluctant to look beyond explicit promises of the parties to a contract, ${ }^{84}$ the court took a more "modern" approach. Announcing that in regard to these contracts courts should seek to enforce the actual understanding of the parties, the court indicated the appropriateness of an inquiry into the parties' conduct to determine if it indicated an implied contract. $^{85}$

The stated commitment to modern contract principles in Foley was clear. The court recognized that there may be some historical basis for imposing formalistic limitations on employment security agreements, but concluded that the development of modern contract law has eroded any such basis. Consistent with that observation, it concluded that defendant's suggested limitations were inappropriate for the modern employment context. ${ }^{86}$

Interestingly, the court approached the employment situation as comparable to other contractual arrangements, discerning no basis for departing from otherwise applicable general principles. ${ }^{87}$ The court assumed an implied contract would have the same implications and force as an express contract. ${ }^{88}$ The court also reaffirmed Pugh's list of factors for determining whether an implied contract existed. ${ }^{89}$

The embrace of general and modern contract approaches by the court had wide-ranging implications, including limiting formalistic challenges to the plaintiff's claim. For example, the defendant employer in Foley had cited earlier precedent ${ }^{90}$ to argue that the alleged implied contract was barred by the statute of frauds. This argument had been a successful strat-

82. Id. at 375 .

83. Id. at 384 .

84. Id. at $385-86$.

85. Id. at 385 .

86. Id. at $386-87$.

87. Id.

88. Id.

89. The Pugh factors are "the personnel policies or practices of the employer, the employee's longevity of service, actions or communications by the employer reflecting assurances of continued employment, and the practices of the industry in which the employee is engaged." Id. at 387 (quoting Pugh v. See's Candies, Inc., 171 Cal. Rptr. 917 (Ct. App. 1981)). 1984)).

90. Foley, 765 P.2d at 381 (citing Newfield v. Ins. Co. of the West, 203 Cal. Rptr. 9 (Ct. App. 
egy at the intermediate appellate level, where the court had reasoned that if there was a contract prohibiting an employer from terminating an employee without good cause, then the employee had a reciprocal obligation to remain employed for at least a year.

This conclusion led to the Court of Appeal's further determination that because the contract could not be performed within a year, it was barred by the statute of frauds unless it was in writing. In the spirit of more modern contract logic, the Supreme Court rejected this formalistic approach, admittedly resorting to its own bit of formalism with the holding that even a contract for "permanent employment" could possibly be performed within a year because the employee can quit or the employer can discharge for cause. $^{91}$

As forward-looking as it was in terms of contract law, Foley severely restricted potential remedies under the Cleary good faith and fair dealing approach. In the first instance, the court held that good faith and fair dealing claims in the employment context arise from a contractual relationship and are fundamentally contractual in nature, thereby limiting prevailing plaintiffs to only contract, not tort, damages. ${ }^{92}$ This approach makes good faith and fair dealing claims largely redundant. A good faith and fair dealing claim adds to a lawsuit only where the employer acts in bad faith without actually breaching the contract; where the contract is also breached, the employee may obtain the same damages through a breach of contract action. But because the default at-will rule gives employers the contractual right to act unilaterally in any way that does not violate the contract, bad faith is all but limited to breaches of the contract itself. ${ }^{93}$

The court went even further in curtailing the potential utility of good faith and fair dealing claims for employment plaintiffs, however. A realistic reading of Cleary could support the argument that every employment contract (at least for long-term employees) created a duty of good faith, whereby the employer could not terminate the relationship without cause. Foley repudiated this idea, stating that such an interpretation would have the effect of transmuting all at-will contracts into contracts requiring good cause for termination. The court pointed to Labor Code section 2922, which codified the at-will rule, noting that if Cleary was so interpreted the statute "would be eviscerated." 94

91. Foley, 765 P.2d at 381-82. This is the approach of "most modern courts." See ROTHSTEIN ET AL., supra note 7, at 762-63.

92. Foley, 765 P.2d at $389-401$.

93. A minority of states permit the use of the covenant of good faith and fair dealing to challenge employer actions such as discharge. Generally the fear is that it will be used to undermine employer prerogatives and that it is effectively an attempt to impose a just cause requirement on all employment relationships. ROTHSTEIN ET AL., supra note 7, at 765-66. Rothstein argues that use of the covenant typically does not involve job security provisions, but prevents employers from depriving employees of benefits already earned. $I d$.

94. Foley, 765 P.2d at 400 n.39. 
Thus after Foley, in the employment context the covenant of good faith and fair dealing protects only the parties' rights to receive the benefits of the contract. It cannot be the source of substantive duties that are excluded from or contradicted by the contract itself. ${ }^{95}$ Thus reduced in potential, the covenant was rendered meaningless by the at-will rule. If the right to good faith and fair dealing protects only the parties' right to receive the benefit of their agreement, and if their agreement is one that creates an at-will relationship, then there is no agreement to terminate only for good cause. The court declined to read the implied covenant standing alone as imposing such a duty. ${ }^{96}$

In keeping with a contractual understanding of the nature of the employment relationship, California courts after Foley were to look to the intent of the parties to determine whether an implied contract exists and whether it is enforceable. The public policy implications of the employment relationship were subsumed by the private nature of the bargaining process. This resonates in the rationale of contract:

While courts have engaged in a balancing of interests when defining the scope of common law tort duties, when the action is in contract, we defer to the parties themselves to balance the costs and benefits of adopting particular contractual terms - or in the case of implied employment contracts, to the employers determination of what rights and benefits it will voluntarily offer to its employees. ${ }^{97}$

In other words, it is up to the employer to define the terms of its relationship with its employees.

It is interesting to note that the decisions also incorporate the idea that implied contracts are enforceable because of employees' reasonable expectations. ${ }^{98}$ The courts often ask whether the employee could reasonably believe, based on the employer's actions and policies, that she was entitled to certain job protections. ${ }^{99}$ This is potentially a different inquiry than whether the employer's actions and polices express an intent to offer job protections. An employee could have a reasonable belief that she is entitled to job protections even where there is a clear, unambiguous written statement of employer intent to the contrary. In fact, as this Article discusses, employers may take advantage of employees' beliefs about job security, deliberately fostering a perception that job protection policies apply even though they do not intend to follow the policies in all cases.

However, courts have not developed the difference between employer intent and employee expectation inquiries. Courts consider whether an employee's expectations are reasonable by referencing the same set of fac-

95. Id.

96. Id.

97. Scott v. Pac. Gas \& Elec. Co., 904 P.2d 834, 844 (Cal. 1995) (citations omitted).

98. See, e.g., id.; Pugh v. See's Candies, Inc., 171 Cal. Rptr. 917, 927-28 (Ct. App. 1981).

99. See, e.g., Scott, 904 P.2d at 839. 
tors-whether the employee could reasonably believe that the employer's actions and policies express an intent to offer job protections. ${ }^{100}$ I will return to the subject of employee expectations later.

IV.

EFFECTS OF THE IMPLIED CONTRACT DOCTRINE

\section{A. Actions and Reactions-the Employers Act}

Not surprisingly, when employers initially faced implied contract lawsuits, they attempted to alter the terms of the employment relationship to avoid liability. Personnel journals and articles written by legal practitioners in the 1980 s routinely characterized implied contract liability as a growing threat that increasingly favored employees, often using extreme language and distorted empirical support to overstate the actual threat of employer liability. ${ }^{101}$ Lauren Edelman, Steven Abraham, and Howard Erlanger argue that these professional characterizations of implied contract claims influenced the way that employers responded to the change in legal rules. ${ }^{102}$

These publications consistently advised employers to revise their personnel documents and policies to reduce liability. ${ }^{103}$ Studies of employer practices in the 1980s show that employers increasingly used disclaimers and changes to personnel documents to achieve this end. ${ }^{104}$ Moreover, the data suggested that these practices diffused rapidly, with the rate of adoption increasing exponentially from 1980 to $1985 .{ }^{105}$ A 1984 survey determined that many of the responding employers made changes to their personnel practices to reduce liability for implied contract claims. Specifically, $43 \%$ revised their handbooks, $36 \%$ revised their employment applications, $25 \%$ issued a policy statement notifying employees that they were employed at will, and $20 \%$ added an at-will clause to their offer letters. ${ }^{106}$

100. For example, in Guz, the California Supreme Court phrased the key question as "whether the parties' conduct was intended, and reasonably understood, to create binding limits on an employer's statutory right to terminate the relationship at will." Guz v. Bechtel Nat'l, Inc., 8 P.3d 1089, 1103-04 (Cal. 2000). However, employees' expectations are determined by employers' conduct: "The issue is whether the employer's words or conduct, on which an employee reasonably relied, gave rise to that specific understanding." Id. at 1105.

101. Lauren B. Edelman et al., Professional Construction of Law: The Inflated Threat of Wrongful Discharge, 26 LAW AND SOC'Y REV. 47, 61-67 (1992). The authors hypothesize that personnel and legal professionals overstated the threat of implied contract liability to create a market for their own services. Id. at 74-76. In reality, the threat of liability was low. Even in the employee-friendly State of California, employees prevailed in only $15 \%$ of the reported implied contract decisions from 1980 to 1989. Id. at 57, Table 1.

102. Edelman, supra note 101.

103. Id. at 67.

104. Id. at $79-80$.

105. Id.

106. Id. (citing Alan F. WEStin \& AlFred G. Feliu, Resolving EMPloYment Disputes WITHOUT LITIGATION (1988)). 
The most basic approach was to insert a legal disclaimer in the employment documents, often the employee handbook. A typical early disclaimer was simply a statement of the employer's intent that employment be at will. ${ }^{107}$ The initial judicial response to the disclaimers was negative, at least in California. Courts retained their liberal interpretation of the employment contract and continued to express a concern for fairness to the employee.

For example, in Wilkerson $v$ Wells Fargo Bank, ${ }^{108}$ the Court of Appeal considered a discharge situation in which the bank's handbook and its service and operations manual expressly set forth the at-will rule as a disclaimer. The plaintiff asserted that two officers and an executive vice president had told him to the contrary that employees would only be fired for good cause. ${ }^{109}$ The court first found that the disclaimer was no bar to arguments that there was an implied contract, rejecting the bank's assertion that the handbook served as an express contract. Further, the court also found the parol evidence rule was not applicable and refused to bar evidence of the alleged oral statements. Earlier cases in which there had been a specific, integrated written agreement precluding the use of such evidence were distinguished on those grounds. The disclaimer language was not dispositive, but merely one of many factors to consider in determining whether there was an implied contract.

The California Supreme Court was not as willing to completely defang disclaimers, instead viewing them as valid expressions of employer intent. In Guz v Bechtel National, Inc. ${ }^{110}$ the court clarified the rules regarding disclaimers and, in the process, gave employers a road map for making their disclaimers more effective.

Guz introduced evidence of three personnel policies which he claimed Bechtel violated: 1) termination for poor performance would be preceded by progressive discipline; 2) layoffs during workforce reduction would be based on objective criteria; and 3) employees laid off during workforce reduction would receive placement and reassignment assistance. ${ }^{111}$ In addition, a Bechtel executive offered corroborating testimony that company practice was to terminate employment only for good cause and to reassign a laid-off employee when possible. ${ }^{112}$

In response, Bechtel offered into evidence its written at-will disclaimer statement that "employees have no agreements guaranteeing continuous service and may be terminated at Bechtel's option." Consistent with the

107. One example of such a disclaimer can be found in Wilkerson v. Wells Fargo Bank, $261 \mathrm{Cal}$. Rptr. 185, 189 (Ct. App. 1989).

108. Id.

109. Id.

110. 8 P.3d 1089 (Cal. 2000)

111. Id. at 1107-08.

112. Id. at 1107 . 
approach of the Court of Appeal in Wilkerson, the California Supreme Court acknowledged that such an expressed disclaimer presents evidence of the intent of the parties but is not controlling, and affirmed that such provisions do not bar other evidence of the employer's intent to enter into contractual obligations. ${ }^{113}$

However, the California Supreme Court went on to note that an implied contract assertion would be particularly likely to overcome an express disclaimer where other provisions in the personnel documents suggest explicit self-imposed limits on the employer's termination rights. ${ }^{114}$ Although it had included a general disclaimer, Bechtel's written policies also contained detailed procedures for terminating employees in specific situations. For example, the handbook provided that laid-off employees were entitled to advance notice, job search assistance, and possible reassignment to another position at Bechtel. ${ }^{115}$ In addition, employees could only be fired for unsatisfactory performance after they had been advised of specific shortcomings and given an opportunity to improve their performance. ${ }^{116}$

The court held that a reasonable trier of fact could find these specific provisions enforceable despite the general disclaimer. ${ }^{117}$ In doing so, the court used a general principle of contract law: more specific provisions control over more general provisions. The court questioned whether employees could reasonably believe that the specific protections set forth were in fact overruled by the general, boilerplate language of the disclaimer found elsewhere in the employee handbook. ${ }^{118}$ In adopting this approach, the court suggested that it was persuaded by general fairness concerns and was not unaware of the actual nature of the employer/employee relationship. ${ }^{119}$ The language is revealing: "handbook disclaimers should not permit an employer, at its whim, to repudiate promises it has otherwise made in its own self interest, and on which it intended an employee to rely." "20

Acknowledging equities on the side of the employer, the court in a footnote conceded that the probative value of a disclaimer depended on its clarity, scope and prominence. ${ }^{121}$ Thus, it held out the possibility that a well-crafted disclaimer might suffice to conclusively determine that employment was at will. The court balanced the employers' traditional free-

113. Id. at 1103. In contrast, twenty-two states ceded to employers at this point in the game, holding that a written disclaimer nullifies employer representations if the disclaimer is unambiguous and prominent. David J. Walsh \& Joshua L. Schwartz, State Common Law Wrongful Discharge Doctrines: Up-date, Refinement, and Rationales, 33 AM. BuS. L.J. 645 (1996).

114. Guz, 8 P.3d at $1107-08$.

115. Id. at 1108 .

116. Id.

117. Id. at 1107-08.

118. Id.

119. Id. at 1103 .

120. Id.

121. Id. at $1104 \mathrm{n} .11$. 
dom against the employee's likely expectations, suggesting that employee reliance was a significant factor. The burden fell on the employer to use prominent, clear and consistent disclaimer language in handbooks, policy manuals, and memoranda disseminated to employees. The more explicit and detailed the disclaimer, the greater the likelihood that workers could not form any reasonable contrary understanding. ${ }^{122}$

\section{B. Additional Employer Strategies}

Unsurprisingly, employers sought ways to strengthen the at-will statements in their personnel documents. However, anticipating the significant benefits of progressive policies on the job market, employers did not immediately abandon job protection policies in their employee handbooks even as courts began to enforce them. ${ }^{123}$ Instead, employers tried drafting clearer and more complete disclaimers. They also attempted to create express contracts of at-will employment with their employees without actually offering a complete employment contract. Reactions by the courts were confusing and often contradictory.

One strategy employers attempted was to insert into their personnel documents disclaimers stating that the documents are "not intended to give rise to contractual rights or obligations." 124 Employers hoped that by using this language, courts would be unable to find that the policies contained in their personnel documents constituted enforceable contracts. This strategy worked in some cases. ${ }^{125}$ However, in other cases it backfired. For example, in Reid v. SmithKline Beecham Corp. ${ }^{126}$ the employer tried to rely on at-will disclaimers in its employment application and handbook to preclude evidence of an implied contract. However, both documents contained statements that they were not intended to be contracts. The court therefore held that the disclaimers were not contractually binding. The plaintiff was allowed to present evidence of the employer's practice of terminating only for good cause, thereby raising a triable issue of fact regarding the existence of an implied contract. ${ }^{127}$

Employers also added disclaimers to the sections of the handbook that set forth job protection policies. In Haggard $v$. Kimberly Quality Care,

122. Id.

123. I do not intend to suggest that there was a clear, regimented timeline for employer reactions to judicial decisions. Instead this Part attempts to trace general trends in employers' attempts to avoid liability for implied contract claims.

124. Haggard v. Kimberly Quality Care, Inc., 46 Cal. Rptr. 2d 16, 25 (Ct. App. 1995).

125. Id. Haggard demonstrates a particularly effective use of this strategy. In that case, the employer disclaimed its handbook by stating that it was not intended to create contractual obligations, and at the same time had employees sign an agreement explicitly stating that their employment was at-will. The court held that the handbook was not a modification of the express contract. Id. The use of express at-will agreements is discussed more fully infra.

126. 366 F. Supp. 2d 989 (S.D. Cal. 2005) (applying California law).

127. Id. at $994-95$. 
Inc., ${ }^{128}$ for example, the employee handbook contained a progressive discipline policy. That section of the handbook also contained the following statement: "The company may utilize a system of progressive discipline, at its sole discretion, in cases of misconduct or unacceptable performance. The use of such a system does not waive either the company's or your right to terminate employment at any time with or without cause." ${ }^{29}$ The court found this handbook inconsistent with the employer's intent to alter the atwill relationship between the parties. ${ }^{130}$

While employers experimented with disclaimers, they also explored another strategy to avoid implied contract claims: having employees sign a piece of paper including an express statement that employment is at will. The paper could be an employment application, offer letter, acknowledgement of receipt of employee handbook, confidentiality agreement, or noncompete agreement. This strategy takes advantage of the general contract principle that there can be no implied contract that directly contradicts the terms of the express agreement between the parties. ${ }^{131}$

Courts often frame this issue in terms of the parol evidence rule. Where there is an express contract, parol evidence is admissible only to prove an interpretation of the contract to which the express language is reasonably susceptible. ${ }^{132}$ In the employment context, this means that express at-will contract language prevails even where the employee can point to employee handbook provisions, employer practices, or oral assurances suggesting that the company intended to follow certain job protection policies. ${ }^{133}$

Courts generally enforce express at-will language as long as it is included in a valid contract signed by the employee. ${ }^{134}$ However, employees

\footnotetext{
128. Haggard, 46 Cal. Rptr. $2 \mathrm{~d}$ at 25 .

129. Id.

130. Id. The handbook also contained general disclaimers stating that employment was at-will. Id. at 20 .

131. See, e.g., id. at 21-24; Shapiro v. Wells Fargo Realty Advisors, 199 Cal. Rptr. 613, 621-22 (Ct. App. 1984).

132. E.g., Pacific Gas \& Elec. Co. v. G.W. Thomas Drayage \& Rigging Co., 442 P.2d 641,644 (Cal. 1968).
}

133. See, e.g., Halvorsen v. Aramark Unif. Servs., Inc., 77 Cal. Rptr. 2d 383, 385 (Ct. App. 1998) (personnel policies, employer practices, communications by the employer reflecting assurances of continued employment, and industry practices "have no relevance when there is an express contract of employment which states the term of employment.").

134. E.g., Camp v. Jeffer, Mangels, Butler \& Marmaro, 41 Cal. Rptr. 2d 329, 334-35 (Ct. App. 1995). In Camp, plaintiffs signed an acknowledgement that their "employment is at will and can be terminated at any time with or without cause." Id. at 332. The court held that there "cannot be a valid express contract and an implied contract, each embracing the same subject, but requiring different results," even if the express term is not contained in an integrated contract. Id. at 334 (quoting Shapiro, 199 Cal. Rptr. at 622); see also Haggard, 46 Cal. Rptr. 2d at 21-22. Where the express at-will provision is not signed by the employee, it has no preclusive effect. Reid v. SmithKline Beecham Corp., 366 F.Supp. 2d 989, 994 (S.D. Cal. 2005) (parol evidence may be admitted that contradicts express at-will policy in employee handbook where employee never signed acknowledgement that she received and 
were not completely without remedy. Some courts held that an express atwill provision barred evidence of only prior or contemporaneous collateral agreements, not subsequent ones. ${ }^{135}$ Therefore, even if an employee signed an express at-will agreement, she could still rely on evidence that the employer later made promises or adopted a policy that limited its discretion.

To avoid the claim that the employer's stated at-will policy was modified by subsequent policies, practices or oral representations, employers added language purporting to limit how the at-will relationship could be modified. For example, an employee handbook, offer letter, or other personnel document might contain language like:

I understand and agree, my employment is for no definite or determinable period and may be terminated at any time, with or without prior notice, at the option of either myself or the Company, and that no promises or representations contrary to the foregoing are binding on the Company unless made in writing and signed by me and the Company's designated representative. $^{136}$

The presence of such language in a valid, signed contract would often preclude an employee from making an implied contract claim based on subsequent employer actions. ${ }^{137}$

It may appear that employers had found a foolproof method for avoiding liability for implied contract claims; they could simply have employees sign an express agreement stating that employment is at will and that the nature of the relationship cannot be altered except in another express agreement with senior management. Indeed, defense lawyers recommended these very strategies to employers. For instance, in a white paper discussing the impact of $G u z$, defense firm Morgan Lewis provided the following advice:

[E]mployers who intend employment to be terminable at will should convey that intent clearly and consistently in an express written agreement signed by the employee. Factors such as long-term employment, accolades and raises, and other conduct and employer polices, then will be insufficient to transform an at-will employment relationship into one terminable only for good cause. Of course, an at-will agreement should be carefully drafted to ensure that it covers all actions that the employer intends to be at its will and that it cannot be unwittingly set aside by agreements made later by subordinate officials and managers in the organization. ${ }^{138}$

understood handbook provisions).

135. See, e.g., Wagner v. Glendale Adventist Med. Ctr., 265 Cal. Rptr. 412, 418 (Ct. App. 1989).

136. This disclaimer was part of the employee handbook at issue in Lenk v. Total-Western, Inc., 108 Cal. Rptr. 2d 34, 39 (Ct. App. 2001).

137. See, e.g., Tomlinson v. Qualcomm, Inc., 118 Cal. Rptr. 2d 822, 830-31 (Ct. App. 2002); Starzynski v. Capital Pub. Radio, Inc., 105 Cal. Rptr. 2d 525, 527-29 (Ct. App. 2001); Haggard, Cal. Rptr. $2 d$ at 24

138. Morgan, Lewis \& Bockius LLP, The California Supreme Court Extends the String of Gains for Employers Into the Areas of At-Will Employment and Discrimination, Nov. 2000, at 3, 
However, some California appellate courts were not willing to throw in the towel on implied contract claims. While courts did not dispute the wellsettled rule that an implied contract cannot contradict the terms of an express agreement, they had some latitude in determining what constitutes a valid express contract. This area of the law features conflicting Court of Appeal decisions. Some decisions distinguished between an employment application and a contract signed after hiring, holding that the former was not an enforceable contract but rather a solicitation of an offer of employment. ${ }^{139}$ Other decisions held that an employer could not rely on express atwill provisions contained in standardized forms that omitted key terms of the employment relationship. ${ }^{140}$ On the other hand, many courts held that any written agreement containing an at-will provision barred evidence of contrary implied contracts, even if the express agreement consists only of the at-will provision. Some courts held that an express at-will provision had no preclusive effect unless the agreement was integrated, ${ }^{141}$ while others excluded evidence at odds with non-integrated contracts. ${ }^{142}$ Other decisions used the doctrine of partial integration to determine that documents which were not integrated as to their other terms or which omitted other material terms were integrated with respect to employees' at-will status. ${ }^{143}$

These conflicting Court of Appeal decisions resulted in employer confusion. The defense firm Seyfarth Shaw succinctly describes the decisions facing employers: "The temptation to soften 'at-will' language for various recruiting and $\mathrm{HR}$ purposes can be strong, but the risk is that plaintiff's lawyers will attempt to capitalize on inconsistencies and ambiguities and this can lead to expensive litigation." 144 Clearly, certain strategies could significantly reduce employers' exposure to implied contract claims. However, success was not guaranteed, as some courts would let employees have their day in court despite clear disclaimers and express statements of at-will employment. Employers continued to worry about potential liability from following job protection policies. The strategies discussed in this Part all involve employer efforts to clarify their stated intent to enter into a contract

www.morganlewis.com.

139. See, e.g., Harden v. Maybeline Sales Corp., 282 Cal. Rptr. 96, 98-99 (Ct. App. 1991) (application not a contract, and “at-will clause contained in defendants' standardized, preprinted employment application is merely evidence concerning the ultimate agreement entered into between the parties"); see also Jenkins v. Eastern Capital Corp., 846 F. Supp. 864, 870-71 (N.D. Cal. 1994) (noting split in authority but holding application is valid contract).

140. See, e.g., Seubert v. McKesson Corp., 273 Cal. Rptr. 296, 299-300 (Ct. App. 1990); McLain v. Great Am. Ins. Cos., 256 Cal. Rptr. 863, 868 (Ct. App. 1989).

141. See, e.g., Seubert, 273 Cal. Rptt. at 299-300; McLain, 256 Cal. Rptr. at 868.

142. See, e.g., Starzynski, 105 Cal. Rptr. 2d at 528; Halvorsen v. Aramark Unif. Servs., Inc., 77 Cal. Rptr. 2d 383, 385-86 (Ct. App. 1998); Camp v. Jeffer, Mangels, Butler \& Marmaro, 41 Cal. Rptr. 2d 329, 334 (Ct. App. 1995).

143. See, e.g., Wallis v. Farmers Group, Inc., 269 Cal. Rptr. 299, 305-06 (Ct. App. 1990).

144. Seyfarth Shaw LLP, California Labor \& Employment Law Update-Summer 2006, Aug. 2006, www.sey farth.com. 
for employment at-will. At the same time, employers engaged in conduct designed to affect the other side of the courts' analysis - the evidence employees could introduce to show that they reasonably expected to benefit from a job protection policy. Those efforts are discussed in the next Part.

\section{Employers Abandon the Field}

After courts started enforcing implied contractual rights to job security, employers began taking steps to reduce the evidence on which an employee could rely to demonstrate the existence of an implied obligation. While courts' intent in adopting the implied contract rule might have been to make employers live up to their promises, the rule effectively discouraged employers from making any promises in the first place. Paradoxically, the use of the implied contract doctrine to protect employee expectations actually created an incentive for employers to act arbitrarily, avoiding promises of consistency and fairness to reduce liability. An employer who previously discharged employees for no good reason has a stronger defense to an implied contract claim than one who consistently based its discharge decisions on merit and followed certain established procedures.

The possibility of implied contract liability created competing incentives for employers regarding the manuals. Employers were forced to decide whether retaining beneficial employment security policies was worth the risk of legal liability or the curtailment of their historical freedom. In an article directed at employers and published on a website for small businesses, a group of professors led by Patricia Borstorff summarizes these competing interests. ${ }^{145}$ The article notes that while employment at-will disclaimers may help avoid legal liability, they can have a negative impact on attracting and retaining talented, dedicated employees. ${ }^{146}$ " $\mathrm{A}$ manager is faced with a judgment call between maximizing legal protection and presenting the corporate culture as one that is stiff, legalistic, and mistrustful." 147

In the $1980 \mathrm{~s}$, after the first wave of implied contract claims, commentators noted that some management lawyers were advising their clients to avoid using employee handbooks, or at least to omit from them any provisions dealing with job security. ${ }^{148}$ Some observers questioned whether there would be a large-scale abandonment of employee handbooks. The original consensus was that the benefits from handbooks and other formal

145. Patricia Borstoff et al., Employment-At-Will: Communicate or Abandon? (2004), www.sbaer.uca.edu/research/asbe/1997/PDF/06.pdf.

146. Id. at 1 .

147. Id. at 4 .

148. E.g., John D. Coombe, Employee Handbooks: Asset or Liability?, 12 EMP. REL. L. J. 4, 10 (1995); see also Edelman, supra note 101, at 67, 79 (empirical study suggests many employers followed recommendations from legal professionals to remove such language from personnel documents in the 1980s). 
policies outweighed the increased risk of litigation. Predictions were that few employers would give them up. ${ }^{149}$

In hindsight, this speculation proved to be incorrect. Unable to find a liability-proof disclaimer that would insulate them from all implied contract claims, some employers simply gave up on setting forth comprehensive voluntary progressive policies. Instead, employers drafted vague, overly general statements from which no specific protections for employees could be implied, or they ceased writing policies altogether.

The trend towards removing job protection policies from handbooks can be seen in the facts of California decisions. In Wagner v. Glendale Adventist Medical Center, ${ }^{150}$ for example, the court describes how the employee handbook changed over the years. In 1977, the handbook contained a general disclaimer that employment is "based on mutual consent," meaning either party may terminate employment. Nevertheless, a section of the handbook dealing with "dismissal" predicated termination of employees only for poor job performance or misconduct. ${ }^{151}$ This section of the handbook was modified in 1983 to add the words "at-will" to the disclaimer language. In 1986, the dismissal section of the handbook was completely rewritten. Replacing the section detailing the reasons for dismissal was a new section regarding "discipline," which provided that discipline "may consist of verbal warning, written warning, suspension without pay, and/or discharge depending on the seriousness of the infraction." 152 No longer does the policy limit the reasons for discharge. The same section of the handbook also contains a disclaimer stating that employment is at-will and that the information contained therein "is intended as a guideline and is not meant to create a contractual relationship." 153

When the first implied contract cases were decided, employees could point to relatively clear evidence showing that boilerplate expressions of the at-will rule did not accurately describe the real agreement between the parties. Employers had often disseminated written job protection policies to their employees. ${ }^{154}$ Managers and supervisors testified that they followed unwritten policies and practices limiting their discretion under the at-will rule. ${ }^{155}$ Employers also made explicit oral promises to employees regarding

\footnotetext{
149. Coombe, supra note 148.

150. 265 Cal. Rptr. 412 (Ct. App. 1989).

151. Id. at 417 .

152. Id. at 421 .

153. Id.

154. In Foley, for example, the employer maintained written guidelines that listed the acceptable grounds for discharge and contained a mandatory, seven-step pre-termination procedure. Foley v. Interactive Data Corp., 765 P.2d 373, 375 (Cal. 1988). These procedures were in place during the time of plaintiff's employment, from 1976 to 1983. Id. at 375. Similarly, the plaintiffs in Scott introduced evidence of the employer's written policies mandating certain progressive discipline procedures. Scott v. Pac. Gas \& Elec. Co., 904 P.2d 834, 837 (Cal. 1995). These procedures were in place in 1989. Id.

155. See, e.g., Pugh v. See's Candies, Inc., 171 Cal. Rptr. 917 (Ct. App. 1981). In Pugh, the presi-
} 
their length of employment. ${ }^{156}$

In recent years, employers, reacting to those early cases, put into place devices that make it unusual to find a case with the sort of strong, unequivocal evidence that supports applying an implied contract exception to the at-will rule. ${ }^{157}$ In the few contemporary cases in which employees can point to written job protection policies, those policies will likely be counteracted by prominent disclaimers. Today's managers are wary of representing that employers will follow unwritten job protection practices or giving other indices of assurance. In contrast to many of the early cases, many recent implied contract plaintiffs rely on nothing more than vague statements and tenuous suppositions. ${ }^{158}$

It is important to realize, however, that employers merely have abandoned setting forth explicit policies, not necessarily the underlying practice of the norms that they reflect. Many employers still largely follow job protection policies; they act without formally announcing an intent to do so, thereby minimizing fear of implied contract suits but ensuring the benefits do not disappear. ${ }^{159}$

In retrospect, the abandonment of explicit job protection provisions should not come as a surprise. After all, what do employers lose by walking away from written employment-protection policies? Employers may continue to provide most employees a system of progressive discipline, although with an unwritten, more informal practice than previously undertaken. If the practices are visible, employees will perceive their employer as fair, and the employer will retain the benefits that would have come from more formalized policies, such as employer satisfaction and motivation.

However, it will be substantially harder for an individual employee to bring a lawsuit founded on an implied contract if an employer's policies are

dent and general manager of the company admitted to following a practice of firing administrative personnel only for good cause. Id. at 919. Pugh was terminated in 1973, before California courts began enforcing implied employment contract claims. Id; see also Scott, 904 P.2d at 837 (personnel manager testified that the company followed its progressive discipline policies, and no evidence suggested that they were discretionary).

156. For example, in Malmstrom v. Kaiser Aluminum \& Chem. Corp., the employer did not dispute that it made assurances about the plaintiff's job security during his pre-hire interview. $231 \mathrm{Cal}$. Rptr. 820,823 (Ct. App. 1986). The plaintiff was told by the person that hired him that his "job would continue as long as he performed his work satisfactorily," and that the company never terminated anyone except for good cause. Id. This interview occurred in 1976. Id.

157. I do not mean to suggest that every California employer has altered or abandoned their employment policies, or that all California employers had such written policies before 1980 . Instead, this article discusses general trends in a diverse workplace.

158. For example, in the recent case Kelly v. Stamps.com Inc., plaintiff asserted that she was protected by an implied contract that she could only be terminated for good cause. 38 Cal. Rptr. 3d 240, 242 (2005). Her only evidence of such an implied agreement, however, was the fact that she was awarded a retention bonus in October 2000 which had a second installment due in April 2001. Id. at 251. While the bonus may have reflected a desire by the employer in October 2000 that plaintiff remain employed until April 2001, the court held that it was not a promise to retain the plaintiff. Id. at 251-52.

159. See Rudy, supra note 41 . 
not in writing. Without a written policy, it is much more difficult for an employee to prove that her employer promised or intended to be bound to any specific practice or process.

It is therefore somewhat surprising how long employers held on to their written policies and the lengths to which they went to craft a disclaimer that both attracted employees by setting out progressive policies while not really ceding any of the traditional power enjoyed by the employer under the at-will rule. This demonstrates that employers recognized the potential value employees place upon job protection policies. A handbook, or any other written expression of employer policy, is a unique way for employers to communicate with employees and present a positive image. ${ }^{160}$ Handbooks function as a "symbol of stability and security" for employees. The fact that policies are written down and distributed to employees makes them seem more substantial and suggest a greater commitment by the employer. ${ }^{161}$

There is one additional consideration. Aside from their role in recruiting employees, employers may correctly perceive that there is independent value in having written, rather than informal, policies. For one thing, in formulating or implementing formal rules, individual managers are encouraged to think about big picture and general policies while making decisions about how to treat individual employees. Uniformity and efficiency are easier to achieve by resorting to formal policies, rather than on an ad hoc basis with the potential for appeal and argument. The point is that the nonlegal norms reflected in handbooks, practices, and polices structure the workplace even if they are not enforceable in courts of law.

Employers' response to the implied contract doctrine may have lasting effects on the very nature of the workplace. Loss of explicit job protection policies may lead to many more violations of fairness norms that had been developing under employers' voluntary policies. More ad hoc, less standardized rules may mean less protection for individual workers and for workers in general. What has been lost is the non-legal voluntary protection that employers were developing in response to industry and competitive pressures.

\section{The Courts Respond}

Although many view the law in California regarding implied employment contract claims as a confusing morass of contradictory opinions, there are trends in the supposed chaos. Over time, courts became increasingly likely to value employers' express disclaimers or at-will provisions over employees' assertion that employers' conduct gave rise to an implied understanding of job security. Similarly, courts were increasingly likely to

160. Coombe, supra note 148 , at 10-12.

161. Id. at 13 . 
use formalistic contract doctrines, such as the parol evidence rule and the partial integration rule, to hold as a matter of law that employees could not prevail on an implied contract claim.

The "chaos" created by divergent Court of Appeal decisions was significantly lessened by a 2006 decision by the California Supreme Court, Dore v. Arnold Worldwide, Inc. ${ }^{162}$ In that case, the employee received an offer letter describing his commencement date, salary and benefits, and initial probationary period. The letter also contained a paragraph stating that employment would be at-will and that "Arnold Communications has the right to terminate your employment at any time just as you have the right to terminate your employment with Arnold Communications, Inc. at any time."163

Plaintiff "signed the letter, signifying his acceptance of [the various] employment terms." The court affirmed that this express language alone was sufficient to bar an implied contract claim. ${ }^{165}$ The decision is significant because it gives the California Supreme Court stamp of approval to a particular employer strategy for avoiding implied contract claims. In the future, employers know that if they include express at-will language in an offer letter signed by the employee, the parol evidence rule will bar the employee from making an implied contract claim. Although not explicit in the decision, Dore also implicitly settles some of the conflicts in the lower court. For example, the offer letter at issue did not have an integration clause, nor did it contain all of the material terms of the employment relationship. However, neither of these issues prevented the court from using the parol evidence rule.

Dore was immediately hailed by defense lawyers. According to a prominent California legal newspaper, the decision "is a boon for the business community and clarifies an area of the law that had gotten increasingly murky because of conflicting appellate court opinions in recent years."166 Defense firm Jones Day expressed similar sentiments in a commentary posted on its website shortly after the decision. Jones Day called Dore "an important decision for employers" that "confirms that employers who in-

162. 139 P.3d 56 (Cal. 2006)

163. Id. at 58 .

164. Id.

165. Id. at 60-61. It could be argued that Dore left the door open for implied contract claims through the doctrine of latent ambiguity. According to that doctrine, extrinsic evidence is admissible if it could reveal more than one possible meaning of a contractual term even though the term is unambiguous on its face. Id. at 60 . The court determined that there was no such ambiguity in the present case, but reaffirmed the basic validity of the latent ambiguity concept. Id. However, the supposed ambiguity in Dore centered on the employer's description of the at-will relationship as one that can be terminated "at any time" without also stating that employment can be terminated "for any reason." Id. As a result, employers can avoid any latent ambiguity argument by using language that specifically states that employment can be terminated at any time, for any reason.

166. Mike McKee, Calif. High Court: No Mystery to Employee's "At-Will" Contract, THE RECORDER, Aug. 7, 2006. 
clude at-will language in their offer letters will be able to defeat breach-ofcontract and misrepresentation claims based on an employee's allegations of assurances of long-term employment."167

Attorney Paul Siegel of the defense firm Jackson Lewis interpreted the decision even more broadly, asserting that the court "adopt[ed] a rule that provides solid legal ground for an unambiguous statement in an offer of employment that the parties agree to 'at-will' status whereby the agreement may be terminated at any time and for any or no reason by either party." He further stated that the "clear and succinct decision is a relief for California employers in helping to navigate the treacherous waters of defining the terms of employment." 168 The law firm Sedgwick, Detert, Moran \& Arnold is similarly strong in its analysis: "In light of Dore v. Arnold, if an employer is careful to use at-will language in employment documents, employees will be hard pressed to pursue wrongful discharge claims premised on a breach of contract theory." 169

As things currently stand in California, as long as employers are careful when drafting documents, there is now little chance that they will be liable for an implied contract claim.

\section{V. PRIVATE CONTRACT IS THE WRONG REMEDY}

Given that the law conceptualizes employment primarily as a matter of private concern governed by contract, it is not surprising that courts initially turned to contract law to address the problem of employers failing to live up to workplace norms. ${ }^{170}$ Perhaps the contract route initially seemed suffi-

167. Robert T. Clarkson \& Donna M. Mezias, California Supreme Court Buttresses "At-Will" Defense to Employment Claims, JONES DAY COMMENTARIES, Aug. 2006, www.jonesday.com.

168. Paul J. Siegel, "Simple Logic" Precludes Ambiguity in Offer Letter's At-Will Clause, INT'L RISK MGMT. INST., Sept. 2006, www.irmi.com/expert/articles/2006/siegel09.aspx.

169. Sedgwick, Detert, Moran \& Amold LLP, Alert! At Will is Alive and Well in California, EMPLOYMENT BRIEFINGS AlERT, Aug. 2006, http://www.sdma.com.

170. Until the latter part of the 20th century, it would have been unthinkable to use something other than contract doctrine to limit an employer's power to terminate the employment relationship. In Adair v. United States, 208 U.S. 161 (1908), the Supreme Court invalidated the Erdman Act of 1898, which was enacted to prevent disruption of interstate commerce by labor disputes. The act protected union members by prohibiting yellow dog contracts and the discharge or blacklisting of employees for union activity. An employer who discharged an employee for union membership challenged the constitutionality of the statute. Writing for the majority, Justice John Marshall Harlan posited equal bargaining power between employer and employee. He held the law to be an unreasonable invasion of personal liberty and property rights guaranteed by the due process clause of the 5th Amendment. Relying on 14th Amendment precedents, Harlan grafted the substantive conception of due process and freedom of contract onto the 5th Amendment. He also found the act to be outside the scope of congressional commerce power. Ignoring the statute's legislative history, he asserted there was no "legal or logical connection" between union membership and interstate commerce. Id. at 178. Justice Joseph McKenna, in dissent, called for judicial realism, whereas Justice Oliver Wendell Holmes echoed the position of restraint he had espoused in Lochner v. New York, 198 U.S. 45 (1905); the legislature was the proper arbiter of pub- 
cient to address the more egregious policy concerns about the inequities in the employment relationship. In fact, the implied contract remedy showed some initial promise when it was adopted, but the courts that followed this route were eventually left with an ineffective framework. Classical contract law, as it has been construed under the influence of the at-will rule, simply has not been a flexible and nuanced enough vehicle for monitoring fairness in the employment relationship.

I do not argue that courts are incapable of using equitable considerations to mitigate formalistic contract interpretation. There are many judicial decisions that reach a result seemingly contrary to traditional contract principles because the court was more concerned with reaching a fair result. Although the prevailing trend now appears to be relatively formalistic, courts are quite capable of interpreting contract principles flexibly to enforce the actual agreement between the parties rather than the written language of the document. So why have courts been unable or unwilling to do so in the context of implied employment contracts?

\section{A. The Limits of Contract}

Some commentators believe that California courts simply became more conservative over time. While this change in the makeup of the judiciary undoubtedly affected implied contract decisions, we must also examine the shifting factual circumstances that presented themselves to the courts. After all, courts do not make decisions in a vacuum, but respond to situations as they evolve. Actions and reactions generate unanticipated issues and must subsequently factor into the courts' evolving approach to a series of situations. When placed in the context of employers' changing behavior, the courts' apparent retreat into formalism may also be an inevitable response to those changes.

\section{The Power of One-Sided Drafting}

When a court wishes to look beyond the express terms of an agreement for equitable reasons, it may do so in various ways. First, a court may flexibly interpret existing contract doctrines by either 1) finding ambiguity in the agreement, later modifications, or contradictory terms; or 2) finding technical deficiencies in the formation of the at-will contract. As described in the preceding section, California courts used both of these strategies to

lic policy and could reasonably limit freedom of contract.

Conservatives extolled Adair for condemning "class legislation," while Roscoe Pound thought it epitomized "mechanical jurisprudence," the use of "technicalities and conceptualizations" to defeat the ends of justice. Roscoe Pound, Liberty of Contract, 18 YALE L. J. 454, 469 (1909). The precedent supported invalidation of state laws providing similar protections for unions, Coppage v. Kansas, 236 U.S. 1 (1915), until the New Deal era revolutionized labor-management relations. 
enforce employee expectations in the workplace.

As discussed above, courts initially had some success in finding ambiguity, modifications, or terms contradictory to at-will employment. In early cases, it was often relatively easy for the courts to find that at-will agreements were ambiguous. Where there was no written statement of the employers' at-will policy, courts were free to examine the entire range of conduct between the parties and could easily find evidence that rendered the employer's at-will position ambiguous or contradictory. Where there were express statements of at-will intention, employees in earlier cases could often point to specific handbook provisions, admitted practices, explicit policies, or oral promises to the contrary. ${ }^{171}$ Again, these facts helped courts use traditional contract law principles to achieve a fair result.

However, employers changed the landscape of the employment relationship, making it more difficult for courts to play with contract principles to achieve a desired result. In later cases, there were often no other policies, practices, or promises that contradicted or rendered ambiguous the employer's stated intent of employment at will. Employers utilized more explicit disclaimers and written affirmations of at-will employment. As the facts became increasingly one-sided, courts were less and less able to conclude that the employer's intent was unclear. Likewise, the changing facts made it increasingly difficult for courts to find that the at-will agreement had been modified by subsequent conduct.

Similarly, changes in employment contract language made it more difficult for courts to find technical flaws with contract formation. As discussed supra, some California appellate courts tried various strategies to rule that express at-will agreements were unenforceable. However, employers would simply redraft their personnel documents to avoid the problem in the future. Eventually, employers were able to come up with technically unobjectionable contracts.

Although courts are often willing to liberally interpret contract theory to combat perceived unfairness in the employment relationship, this approach is limited. To challenge employers' stated intent, courts need ambiguity or conflict. To challenge contract formation, courts need drafting mistakes.

As many scholars have noted, the typical employment contract does not arise from an equal bargaining process. ${ }^{172}$ Most employees have little

171. See supra text accompanying notes 148-53.

172. E.g., Andre D. Bouffard, Emerging Protection Against Retaliatory Discharge: A Public Policy Exception to the Employment At-Will Doctrine in Maine, 38 MAINE L. REV. 67, 70 (1986). ("In the last two decades, however, courts and commentators have recognized that, because the mutuality of obligations rationale is based on the false premise of relatively equal bargaining power between employees at-will and employers, the traditional employment at-will doctrine has little or no legitimate economic justification."); Lawrence E. Blades, Employment At Will vs. Individual Freedom: On Limiting the Abusive Exercise of Employer Power, 67 COLUMBIA L. REv. 1404, 1411-12 (1967) (discussing potential abuses of power resulting from unequal bargaining power between employers and employees). 
control over the terms and conditions of their employment. Instead, the employer is in control of the relationship. Employers have the practical ability to structure the relationship however they see fit. ${ }^{173}$

Employers generally draft all policies, contracts, and other written indicia of the employment relationship. Equally indicative of the one-sided nature of the relationship is that employers are at liberty to alter existing documents at their sole discretion to avoid unwanted liability or to eliminate practices deemed unnecessary or inefficient. ${ }^{174}$ These documents form the primary evidentiary tool from which courts determine the intent of both of the parties and interpret the terms of their contractual relationship.

If a court decides to liberally interpret contract law to thwart employer aims, employers can rewrite their existing or future documents to close off that possibility. When the courts stretch contract doctrine to benefit employees, employers can use that same doctrine to guide their rewriting of personnel documents that make up evidence of the employment contract, thereby minimizing those benefits. More starkly, employers can simply retreat from providing documents that might evidence contractual expectations altogether and simply revert to an unembellished at-will rule.

We see this dynamic play out in the disclaimer cases discussed supra. In $G u z$, the court went to great lengths to preserve the implied contract remedy in the face of an explicit disclaimer that the employer did not intend to assume any contractual obligations or modify the at-will rule. Despite the court's holding, the court admitted that employers could theoretically structure the relationship in such a way that the intent for at-will employment was clear and unambiguous. ${ }^{175}$ This concession to the primacy of intent, mandated by traditional contract principles, left the door open for employer innovation-an opening that allowed employers to keep the at-will prerogative intact.

The problem with traditional contract law, and the reason I argue that it is the wrong tool to deal with the problem of employer opportunism identified by the courts, is that it cannot be used to import an extrinsic set of rules into the employment relationship where the intent of the contract is unambiguous and the contract has been properly formed. Traditional contract law enforces the agreement between the parties, even if outsiders might view that agreement as unfair. Given the unequal nature of the typical employment relationship, this means that contract ultimately cannot prevent employers from structuring the employment relationship as they see fit. In order to impose outside rules or norms on the employment relationship, we must look to some tool other than traditional contract law.

173. However, employers' control of the workplace is not monolithic. Some employees have relatively more bargaining power and are able to dictate terms to their employers.

174. See Asmus v. Pacific Bell, 23 Cal. 4th 1 (2000).

175. Guz v. Bechtel Nat'l, Inc., 8 P.3d 1089, 1104 n.11 (Cal. 2000). 


\section{At-Will Entrenchment}

Even if workplace changes have made it impractical for courts to use traditional contract doctrines to challenge express at-will agreements, courts still have other options. Courts may look to a larger public policy that justifies deviating from the parties' intent. Even if the terms of a contract are clear, a court could determine that the contract should not be enforced. However, it is unlikely that courts would so act, considering the significant entrenchment of the at-will rule in American public policy. Using public policy to enforce implied employment contracts in this context would necessarily involve a policy judgment about the at-will rule.

The "unfairness" that courts sought to address in creating the implied contract remedy was the employer's reliance on the at-will rule to the detriment of its employees who believed they would receive job protections. As long as the claim was framed as a matter of employer choice, the remedy did not conflict with the at-will rule. Employers were, at least theoretically, still free to refuse to offer job protections and engage in genuine atwill employment. However, if they chose to offer job protections, even impliedly, they had to abide by that choice.

This calculus changes where an employer can successfully remove any doubt as to its intention to offer employment at-will. Are employees reasonably entitled to job protections even where the employer clearly does not intend to offer them? As discussed supra, employers may take advantage of employee's misunderstanding of the law even if it uses clear and explicit statements of at-will employment. Employees' belief that they are entitled to job protections could be based on the informal practices of most employers, most notably progressive discipline and termination for cause. These historic practices have generated workplace norms which many employees expect employers to follow regardless of at-will contracts or disclaimers.

A court could conclude that employee expectations in this situation are reasonable and enforceable in contract as a matter of public policy. But to do so would present a significant challenge to the at-will rule. Essentially, courts would be holding that employers who try to opt out of providing job protections are stuck with those protections anyway. This is a direct conflict with an employer's right under the at-will rule to unilaterally terminate or alter the employment relationship.

It is unlikely that courts will adopt a new public policy that fundamentally challenges the at-will rule, which is the defining element of American employment law. Indeed, the California Supreme Court made clear its reluctance to challenge the at-will rule even where it is uncontested that the employer had made promises of job security. In Asmus v. Pacific Bell, ${ }^{176}$ there was no question that the employer had created an implied contract, 
which prevented it from firing employees without good cause. ${ }^{177}$ The issue for the court's consideration in Asmus therefore was not contract formation, but whether the employer could unilaterally modify the implied contract to revert back to an at-will employment arrangement.

The general principle governing contract law in California at that time was clearly articulated in the dissenting opinion of Chief Justice George: one party cannot unilaterally modify the terms of an existing contract. The dissent noted that the law was clear that a party wishing to modify a contract must both provide new consideration and obtain the acceptance of the other party to change its terms. ${ }^{178}$ The majority, however, sided with the employer, imposing no such limitations on the modification process in the employment context. Disregarding the generally applicable contract modification rule, the majority held that an employer could unilaterally modify an implied employment contract after giving reasonable notice of intent to do so and if such modification did not interfere with employees' vested benefits. ${ }^{179}$

The court first determined that the employment contract was unilateral. ${ }^{180}$ Under the Restatement (Second) of Contracts, ${ }^{181}$ the rule for unilateral contracts is straightforward: once the promisee begins performance, the offer becomes an option contract that the promisor cannot revoke even though the promisee can cease performance at any time without breaching the contract. This allows an employee through performance to establish acceptance and, thus, enforce the terms of an employment contract, while at the same time preserving her right to leave employment at any time. However, the court held that the employer's modification created a new unilat-

177. There is no legally significant difference between the enforceability of an implied versus expressed contract term. Kashmiri v. Regents of Univ. of Cal., 67 Cal. Rptr. 3d 635, 650 (Cal. App. 2007) (implied contractual terms ordinarily "stand on equal footing" with express terms).

178. Asmus, 23 Cal. 4th at 31-32 (George, J., dissenting).

179. Id. at 6 (majority opinion)

180. Id. at $8 \&$ n. 4 . In early employment cases, courts cast agreements as unilateral contracts to avoid ritualistic employer challenges to employee contract claims. Employers would claim that the requirements of a bilateral contract were not met because there was no mutuality of obligation. In other words, the employer could not be obligated to continue to employ the employee unless there was a reciprocal obligation on behalf of the employee to remain in employment. The framework of unilateral contract avoided this problem because the employee could accept the contract by working for the employer. This bound the employer to the unilateral contract, but left the employee free to cease performing at any time without breaching the contract. Richard Harrison Winters, Employee Handbooks and Employment-At-Will Contracts, 1985 DUKE L. J. 196, 200-04, 212-15 (1985) (discussing problems with traditional contract doctrine in the employment context and explaining how unilateral contract theory avoids traditional employer defenses); see also Eales v. Tanana Valley Med.-Surgical Group, Inc., 663 P.2d 958, 959-60 (Ala. 1983) (contract of "permanent" employment is enforceable despite employee's ability to terminate relationship because no mutuality of obligation is required in unilateral contracts); Small v. Springs Indus., Inc., 357 S.E. 2d 452, 484-85 (S.C. 1987) (rejecting employer's mutuality of obligation argument because the employment contract is unilateral, not bilateral); Ormsby v. Dana Kepner Co. of Wyo., 997 P.2d 471 (Wyo. 2000) (mutuality of obligation not required in employment contracts because they are unilateral); Demasse v. ITT Corp., 984 P.2d 1138, 1155 (Ariz. 1999) (same).

181. Restatement (Second) of Contracts $\$ 25$ (1981). 
eral contract. It further found that the employee's continued work and the employer's provision of continued employment constituted evidence of acceptance of the new contract. ${ }^{182}$ This result would seem to violate unilateral contract principles.

It is important to distinguish between the consideration required for contract formation versus contract modification. Under established law, no consideration beyond performance is required on the part of the promisee in accepting a unilateral contract, which is an issue of contract formation. On the other hand, once such a contract is already in place, consideration should be required to modify its terms. ${ }^{183}$ Indeed, the whole logic underlying the doctrine relating to unilateral contracts, particularly the rule that the offer cannot be revoked once performance has begun, demands this result. ${ }^{184}$

The Asmus majority apparently realized this conceptual problem, which perhaps explains its extensive discussion of the issue of adequacy of consideration for the modification. However, the court's conclusion that "the availability of continuing employment serv[es] as adequate consideration from the employer" for the unilateral modification is flawed. According to the contract, the employer was already obligated to provide continuing employment consistent with the terms of the original agreement, which in this case provided for termination only with good cause. In fact, if the question revolves around adequacy, the "new consideration" is even less than what the employees received before because the "availability of continuing employment" offered by the employer is now terminable at-will. ${ }^{185}$

Similarly questionable is the court's further assertion that "plaintiffs' continued employment constituted acceptance" of the modified contract. ${ }^{186}$ According to this logic, the employees in Asmus had only two options: 1) accept the contract modification by continuing in employment, or 2) terminate the contract by leaving employment. Faced with an offer to modify a contract, a party should have the option to reject the proposed modification and continue with the contract as originally formed, an option suspiciously

182. Asmus, 23 Cal. 4 th at 14-15.

183. See Stephen Carey Sullivan, Unilateral Modification of Employee Handbooks: A Contractual Analysis, 5 REGENT U. L. REV. 261, 288-93 (1995).

184. Asmus is also inconsistent with the approach taken in a number of other jurisdictions. See, e.g., Demasse, 984 P.2d 1138 (new handbook is merely an offer to modify existing handbook and requires consideration beyond continuing to work); Brodie v. General Chem. Corp., 934 P.2d 1263 (Wyo. 1997) (continuing to work not sufficient for modification and additional consideration necessary when employer attempts to restore at-will status); Torosyan v. Boehringer Ingelheim Pharm., Inc., 662 A.2d 89,99 (Conn. 1995) (continuing to work following issuance of a handbook that substantially interferes with employee's legitimate expectations is not conclusive evidence of consent, but raises a question of fact).

185. Considering the same issue, the Arizona Supreme Court concluded that "any other result brings us to an absurdity: the employer's threat to breach its promise of job security provides consideration for the rescission of that promise." Demasse, 984 P.2d at 1145.

186. Asmus, 23 Cal. 4 th at 15 
missing from the court's opinion. Given that there was a valid contract in place limiting termination to good cause, the employer's attempt to terminate that agreement should have resulted in liability for breach of contract.

The reason for the court's acrobatics in this case is not difficult to determine. The court is explicit in recognizing the policy considerations that underlie its decision. According to the court, the employment relationship is dynamic, and employers must be able to alter their policies to meet the changing needs of their business. In addition to flexibility considerations, the Asmus court cites with approval decisions from other jurisdictions indicating that preventing employers from modifying the terms of employment would undermine traditional employment principles, namely the at-will rule. ${ }^{187}$ Indeed, many of the other jurisdictions that reached a similar result explicitly recognize that the rule is based on public policy grounds rather than traditional contract principles. ${ }^{18}$

Ultimately, Asmus illustrates that the at-will rule is the defining lens through which courts interpret American employment relationships. Where implied contract claims conflict with the policies behind the at-will rule, the at-will rule is likely to prevail even where the employer had previously volunteered to offer job protections. It is therefore unlikely that courts will use public policy to enforce employee expectations regarding job protection. ${ }^{189}$ The courts and many legislatures have addressed the public policy issues, and they have decided in favor of the at-will rule's provision of employer flexibility and management prerogative. ${ }^{190}$

187. This contention makes little sense. The at-will rule is a presumption, and does not imply where the parties agree to another type of relationship. Where the issue is modifying an already existing contract, the parties have chosen to supplant the at-will presumption. Therefore, the at-will rule should be irrelevant.

188. Asmus, 23 Cal. 4 th at 33-34.

189. The California Supreme Court explicitly recognized that it cannot use contract law to balance competing equities. In Scott, the court addressed the issue of whether implied contract claims could be extended to demotions as well as terminations. Scott v. Pac. Gas \& Elec. Co., 904 P.2d 834 (Cal. 1995). The employer argued that the court should engage in a balancing of the employer's interest in managerial discretion with the employee's interest against being treated wrongfully. According to PG\&E, the employee's interest in not being unfairly demoted is less than his interest in not being unfairly terminated. Therefore, employers' interests outweigh employees' interests in demotion cases, and courts should not enforce implied contracts providing protection against demotion without cause as a matter of public policy. The California Supreme Court held that this argument fundamentally misunderstood contract law. "While courts have engaged in a balancing of interests when defining the scope of common law tort duties, when the action is in contract, we defer to the parties themselves to balance the costs and benefits of adopting particular contractual terms-or, in the case of implied employment contracts, to the employer's determination of what rights and benefits it will voluntarily offer to its employees." $I d$. at 844 (citations omitted).

190. The concern in employment cases is that unless employers are allowed to modify implied employment contracts, they could be collared with contractual obligations lasting for the tenure of an employee who might remain with the firm for over thirty years. On the other hand, employees who have invested decades in a firm and followed all the rules expecting that their performance would give them some protection against arbitrary termination have justifiable expectations that employers will live up to their promises. 


\section{B. Contract and Discrimination-Two Different Approaches to the At-} Will Rule

Commentators often situate the implied contract doctrine in employment law as part of a larger trend towards erosion of the at-will rule. ${ }^{191} \mathrm{Ac}-$ cording to this widely-held view, for years courts and legislatures have been busy creating exceptions to the at-will rule. In addition to the implied contract doctrine, anti-discrimination statutes and public policy limitations also contain such exceptions. ${ }^{192}$ Many scholars see these combined changes as cumulative evidence that substantial portions of the judiciary and legislature are beginning to recognize the essential unfairness of the at-will rule. ${ }^{193}$ Some even believe that an increasing number of exceptions to the at-will rule is an intermediate stage in the process of ultimately doing away with the at-will rule altogether. ${ }^{194}$ In the literature, the cumulative effects of both implied contract and these other innovations are described as modifying or limiting the at-will rule because although an employer may still terminate an employee for a good or arbitrary reason, it may not do so for a "bad" reason. ${ }^{195}$ "Bad" is defined as a reason prohibited by statute or public policy. As the number of impermissible reasons grows through additional legislation or affirmations of public policy concerns, the at-will rule is in a sense eroded.

Consistent with this gradual erosion view, when a decision upholds an employer's ability to contract around an implied contract claim, commentators react as though this represents a return to and retrenchment of traditional rules and as undermining of the modern trend to limit the harshness of the at-will rule. Whether or not these exceptions are a genuine erosion of the at-will rule, it is misleading to lump together implied contract claims with the public policy and good faith exceptions.

191. See, e.g., Alfred W. Blumrosen, Strangers No More: All Workers Are Entitled to Just Cause Protection Under Title VII, 2 InDUS. REL. L. J. 519 (1978); Cornelius J. Peck, Unjust Discharges from Employment: A Necessary Change in the Law, 40 OHIO ST. L. J. 1, 1 (1979); Theodore J. St. Antoine, $A$ Seed Germinates: Unjust Discharge Reform Heads Toward Full Flower, 67 NEB. L. REV. 56 (1988); Clyde Summers, Individual Protection Against Unjust Dismissal: Time for a Statute, 62 VA. L. REV. 481, 484 (1976).

192. See supra note 21; Fair Labor Standards Act of 1938, 29 U.S.C.A. $\$ \S 201-219$ (West 2008); Age Discrimination in Employment Act of 1967, 29 U.S.C.A. $\$ \$ 621-634$ (West 2008); Occupational Safety and Health Act of 1970, 29 U.S.C.A. $\$ \S 651-678$ (West 2008); Americans with Disabilities Act of 1990, 29 U.S.C.A. $\$ \S 12101-12213$ (West 2008); Title VIl of the Civil Rights Act of 1964, 42 U.S.C.A. $\$ \$ 2000$ e to $2000 \mathrm{e}-17$ (West 2008); Tameny v. Atl. Richfield Co., 610 P.2d 1330 (Cal. 1980); Petermann v. Int'l Bhd. of Teamsters, Local 396, 344 P.2d 25 (Cal. Dist. Ct. App. 1959); Palmateer v. Int'l Harvester Co., 421 N.E.2d 876 (IIl. 1981); Pierce v. Ortho Pharma. Corp., 417 A.2d 505 (N.J. 1980); Geary v. U.S. Steel Corp., 319 A.2d 174 (Pa. 1974); see also Stephen F. Befort, Labor and Employment Law at the Millennium: A Historical Review and Critical Assessment, 43 B.C. L. REV. 351, 378-80 (2002) (discussing "exceptions" to the at-will rule).

193. See Moss, At-Will, supra note 25, at 341 (arguing that the proliferation of exceptions to employment at-will indicates courts' discomfort with the harsh effects of the at-will rule on employees).

194. See, e.g., Peck, supra note 191.

195. See, e.g., Moss, At-Will, supra note 25, at 300-02. 
There are fundamental qualitative differences between implied contract claims on one hand and antidiscrimination statutes or public policy claims on the other. Implied contract claims are at best neutral with respect to the underlying power and policy choices reflected in the at-will rule. By contrast, antidiscrimination and public policy claims are based on the introduction of other societal values into the employment relationship. For example, in passing the ADEA, Congress essentially determined that there is a public interest in preventing discrimination on the basis of age. ${ }^{196}$ Congress deemed this policy objective more important than any competing interest in employer freedom of action. Legislation like the ADEA and other laws with anti-discrimination and anti-retaliation provisions challenges the very logic of the at-will rule because it limits the employer's unfettered discretion.

Implied contract claims, however, do not erode or even challenge employers' exercise of discretion under the at-will rule. The at-will rule can be overcome by the parties' agreement to create a different type of contractual relationship. Where the parties have entered into a different form of contract, the at-will rule no longer applies. ${ }^{197}$ Recent implied contract decisions have not changed this basic dynamic. An employer may enter into an agreement to limit its own ability to terminate employees, but it has the discretion to enter into such an agreement in the first place. ${ }^{198}$ Unlike antidiscrimination statutes that are imposed independently of employer intent, the implied contract doctrine does not import external, overarching societal norms or values into the employment relationship.

Therefore, the Dore decision, in protecting employers' ability to use express contracts to avoid implied contractual liability, was not a retrenchment of the at-will rule. The implied contract doctrine it employs never repudiated the at-will rule in the first place. Consistent with the concepts underpinning contract theory itself, courts have characterized the implied contract as voluntary in nature and dependent upon the manifestation of employer intent through the establishment of policies to govern the workplace. ${ }^{199}$ It should come as no surprise that some employers would alter the documents used as outward manifestations of their intent by courts to avoid implied contract claims. Far from being a retrenchment of the at-will contract, this is a natural consequence of the way the remedy for its unfairness to the employee was framed by the judiciary.

196. According to the statute's findings and declarations, the intent of ADEA is to remedy practices which disadvantage older workers and cause unemployment and deterioration of skill and morale. 29 U.S.C. $\S 621$.

197. See Feinman, supra note 2 .

198. See, e.g., Asmus v. Pacific Bell, 23 Cal. 4th 1 (2000) (characterizing job security protections as a unilateral contract with terms offered by the employer and accepted by the employee through performance).

199. See, e.g., Guz v. Bechtel Nat'l, Inc., 8 P.3d 1089 (Cal. 2000) 
VI.

\section{LOOKING BEYOND CONTRACT}

\section{A. What are the Real Problems?}

One might ask what is wrong with employers maintaining the upper contractual hand. If employers make clear that they have made no promises of job security, then employees are not misled and there is no problem. But this argument ignores workplace realities.

In fashioning the implied contract approach, the courts focused primarily on the intent of the employer, based on the content of handbooks and other formalized policies. However, another important consideration is what employees should have reasonably expected based on the manifest day-to-day workplace operations. Those interactions exemplify the norms that underlay the policies expressed in the handbooks and manuals. Based on practice and existing procedures, employees develop certain expectations about job security - expectations that can form regardless of the written policies of their particular employer. ${ }^{200}$

In fact, outside of the employment arena, modern contract principles are based on the observation that human expectations and understandings are shaped more by general norms and by the specific actions of others than by formal stated policies. ${ }^{201}$ Just as in other contract situations based on norms and practices, if employers generally follow for-cause standards and use progressive discipline, employees will expect those policies to prevail regardless of disclaimers to the contrary in handbooks and manuals. Further, independent of particular employer actions, employee expectations can be based on prevailing norms in the larger industry, or even perceptions about what society demands of employers in general.

Empirical studies suggest that employees typically do not understand the nature of at-will employment, no matter how clear the disclaimer language or what notification documents they voluntarily sign. Professor Pauline T. Kim conducted the first detailed study designed to determine how well employees understood that they could be fired without cause. ${ }^{202} \mathrm{Her}$ results clearly show that employees vastly overestimate their job-security protections. Indeed, her sample groups had an error rate averaging above $80 \%$ when asked whether employers could terminate employees under various scenarios where employers are entitled to do so, such as for purely cost-

200. Cynthia L. Estlund, How Wrong Are Employees About Their Rights, and Why Does It Matter?, 77 N.Y.U. L. REV. 6, 7 (2002) (discussing ability of employers to exploit employee misunderstandings of workplace job security protections).

201. See, e.g., U.C.C. $\S 2-316$ (2003) (providing that a manufacturer of consumer goods cannot disclaim implied warranties to consumers).

202. Pauline T. Kim, Bargaining with Imperfect Information: A Study of Worker Perceptions of Legal Protection in an At-Will World, 83 CORNELL L. REv. 105 (1997). 
saving reasons. ${ }^{203}$

Professor Jesse Rudy followed up on Kim's research a few years later. ${ }^{204}$ He replicated Kim's study using a different sample population-Kim surveyed people at unemployment offices, while Rudy surveyed employed people in different states than those surveyed by Kim. ${ }^{205}$ Rudy's results mirrored Kim's, demonstrating a widespread misunderstanding of the rule. $^{206}$ Rudy summarizes the results of both studies as follows:

This strong pattern of over-estimation indicates that employees are more than unaware of their at-will status. Not only do they not know about or misapply the at-will doctrine, they hold beliefs about their current level of legal job security that are simply wrong. Employees erroneously believe that the law prevents employers from discharging them in a wide variety of situations where the law does not protect them. ${ }^{207}$

Significantly, these studies also demonstrate that many employees do not understand typical at-will disclaimer language. When asked to apply a policy reserving the employer's right to "discharge employees at any time, for any reason, with or without cause," $74 \%$ of Kim's respondents and 50\% of Rudy's respondents still incorrectly believed that it was unlawful for an employer to fire an employee for purely cost-saving reasons. ${ }^{208}$

On the other hand, employers with access to lawyers, industry organizations, chambers of commerce, and other interest groups typically have a much greater understanding of legal rules. For this reason, employers are able to take advantage of their superior legal knowledge to receive the benefits of employee loyalty while still retaining the right to rely on the at-will rule. ${ }^{209}$ However, as Rudy argues, the existence of widespread misunderstanding about job protection likely means that employers follow job protection practices in most cases. If employers often fired employees without cause, employees would better understand that employers had the right to do so. ${ }^{210}$

As these studies suggest, employees base their expectations on how employers act, not on their employers' specific disclaimers or other written policies, no matter how clearly drafted. In addition, it appears that most employers follow workplace norms regarding job security regardless of

203. Id.

204. Rudy, supra note 41.

205. Id. at 317 .

206. Id. at 326. For example, $89 \%$ of Kim's respondents and $84 \%$ of Rudy's respondents mistakenly believed that it was unlawful to terminate an employee because of personal dislike. Id. Similarly, $87 \%$ of Kim's respondents and $85 \%$ of Rudy's respondents incorrectly believed that an employer cannot terminate an employee who it mistakenly believes has stolen money. Id.

207. Id. at 330 .

208. Id. at 335 .

209. See Bird, supra note 28, at 197.

210. Rudy, supra note 41, at 340-41. 
what their formal policies or disclaimers might declare. ${ }^{211}$ Ultimately, it seems there is widespread agreement and understanding between employers and employees that the workplace should be governed by norms of practice, not legalities of disclaimer, and that practice should follow some basic standards of due process. It was this understanding that California courts were originally trying to address through implied contract principles. ${ }^{212}$

Fundamentally, the issue is not about disclosure. Employers may argue that the solution to the problem is to craft more effective disclaimers so that employees truly understand the nature of at-will employment. However, employees will never understand that employers can legally violate workplace norms until large numbers of employers consistently violate those norms.

Since the empirical evidence indicates that there is widespread compliance with due process norms on the part of employers, employers could assert that there is no need for the law and courts to intervene. ${ }^{213}$ Employers could argue that there are sufficient incentives in the system for them to follow the policies they voluntarily establish. Given the shared perception of fairness, any employer that routinely flouted its own policies would, over time, cease to benefit in the recruitment and retention of employees from the perception of fairness that such practices and policies provide. Only an employer who regularly followed its own policies would have the track record that would allow it to benefit from establishing such practices in the first place.

One response to this argument is that it assumes perfect information on the part of potential employees, an assumption that might not prove valid even for current employees who would have more access to relevant information. ${ }^{214}$ This critique would be particularly appropriate in the context of larger workplaces. Even if knowledge of a termination is circulated, all details might not be evident and employees might assume that someone who has been fired was fired for a good reason, and the expected processes followed. There would be no way to correct such a misperception if there is no centralized mechanism for gathering facts about such situations and con-

211. Id. at $342-43$ (citing estimates that an employee has a less than $1 \%$ probability of being disciplined or dismissed for a reason that would violate a union just cause standard); see also Rock \& Wachter, supra note 39.

212. Scott v. Pac. Gas \& Elec. Co., 904 P.2d 834, 843 (Cal. 1995).

213. Rudy makes precisely this argument. Rudy, supra note 41 .

214. Stewart J. Schwab, Life-Cycle Justice: Accommodating Just Cause and Employment at Will, 92 MICH. L. REV. 8, 26-27 (1993) (reputation is unlikely to fully check employer opportunism, especially with late-career workers, job entrants, small or new firms, or declining companies); see also Scott A. Moss, Women Choosing Diverse Workplaces: A Rational Preference with Disturbing Implications for Both Occupational Segregation and Economic Analysis of Law, 27 HARV. WOMEN'S L.J. 1 (2004) (discussing how it is difficult for prospective employees to get information about which employers harass or discriminate against their workers). 
veying them to employees. ${ }^{215}$

Even if employers have an incentive to voluntarily follow the rules, at best the incentive only ensures that the rules will be followed most of the time if they do not have any legal force. Countervailing incentives might intervene in individual cases, ${ }^{216}$ and the question remains of what, if anything, should happen in those situations where the employer acts inconsistently with its policies and practices. Just because employers have incentives to follow the rules in most cases does not mean we should ignore those situations in which they fail to do so.

\section{B. Leaving Individual Intent Behind}

The reality of asymmetric bargaining power between employers and employees presents important policy concerns and questions. In particular, given the undeniable imbalance, should society act to curtail employers' basically unfettered freedom to act in a unilateral manner outside of collective bargaining situations? Or do the demands of the market mandate that we accept employers' ability to act at will, with few externally imposed legal restraints protecting vulnerable employees?

Certainly the history of doctrinal development in California should convince us that these questions cannot be answered through resort to the language of employment agreements and bargaining alone. We need a solution that is not dependent on these notions, thus taking the policy questions out from under the limitations of contract analysis altogether.

Surveying the California history, it is apparent that courts using contract analysis to address these concerns ended up exactly where they started. Employers are free to imply that all sorts of protections might apply to employees, but unless those suggestions are also encapsulated in formal contractual terms, employers can legally avoid complying with them. ${ }^{217}$

More importantly, not only did application of the implied contract doctrine in California not solve the problems originally identified, it also had lingering negative results. For example, the original cases set up an incentive system that discouraged systematic and orderly employer innovations with progressive employment practices. There are indications that many employers have moved away from desirable employee protective processes. Attempts to use these processes to undermine the historically at-will employment relationship prompted some employers to stop making specific promises, thus avoiding the possibility and expense of litigation. ${ }^{218}$

215. In a union shop, this mechanism for collection and dissemination of information is structured into the workplace through the role of the union.

216. See Moss, At-Will, supra note 25, at $354-55$ (employers sometimes engage in "profitable cheating" in particular cases).

217. See Dore v. Arnold Worldwide, Inc., 139 P.3d 56 (Cal. 2006), and discussion supra Part IV.

218. See discussion supra Part IV. 
Employer reluctance to develop voluntary policies and put them in writing may reverse the positive trends in structuring employment relationships that were emerging before the courts' interventions. The impulse to draw up specific policies may not return regardless of whether employers now know that the current construction of the law does not require employers to follow such policies. As the original cases on implied contract clearly illustrate, there is always the risk that courts looking at the equities years from now could decide differently and mandate that voluntarily established progressive policies constitute part of the employment agreement despite explicit and comprehensive disclaimers to the contrary. ${ }^{219}$

This type of pullback and entrenchment by employers would be a loss to employees. For one thing, the failure to reduce rules to writing makes them more likely to be overlooked, misunderstood, or arbitrarily applied. Without explicit procedures and standards, each employment decision is likely to be addressed ad hoc, with employees having to endure more idiosyncratic, less uniform procedures and rules applied to them.

In addition, the lack of written policies to compare and contrast may also harm employees. The lack of written rules and practices impedes communication among employers or within organizations. With individual workplace policies less likely to be made express there may be less competition among workplaces, as well. Employers will be restrained from using progressive workplace policies as lures in the competition to hire and retain employees-while at the same time there will be a corresponding decrease in opportunities for workplace norms to develop across industries and within localities.

\section{Moving Forward}

Given that there are real problems with unfettered employer discretion that the at-will rule allows in practice, the question becomes how to incorporate enforceable notions of fairness into the employment relationship. This Part will discuss some of the proposals made by others and suggest directions for reform and the need for future work. Rather than set forth a fully-formed proposal for a new mechanism to enforce workplace norms, the remainder of this Article builds upon work done by others and suggests directions for future work.

\section{Existing Proposals}

Scholars have proposed a variety of ways to increase the level of fairness in the employment relationship. Most far-reaching for an American

219. There is some evidence that employers hold erroneous beliefs about the degree to which they are likely to suffer lawsuits. See Estlund, supra note 200. 
legal audience are calls to abolish at-will employment and replace it with a system whereby employers may only terminate employees for "good cause." Whatever the merits of such a change, it is unlikely to occur in our current economic and political contexts. Despite decades of academic condemnation, American employment law is no closer to adopting a generallyapplied just cause standard outside of the union shop context. ${ }^{220}$ Progress towards increasing the level of fairness in the employment relationship must be incremental and made through a middle-ground solution that rests between universal just cause on the one hand and the current system of unfettered employer discretion on the other.

\section{a. Covenant of Good Faith and Fair Dealing}

One middle-ground solution suggested early in the debates about workplace fairness is vigorous enforcement of the covenant of good faith and fair dealing. For example, Murray Tabb in 1987 proposed that this was the best vehicle for enforcing employees' reasonable expectations of fairness. ${ }^{221}$ According to his proposal, employers would be liable for breaching the covenant of good faith and fair dealing if they fired employees in bad faith. While he does not define what acts constitute bad faith, one assumes that it would include more reasons than existing discrimination and whistleblower laws. Under Tabb's proposal, employers would continue to be able to fire employees for an arbitrary reason or for no reason at all. ${ }^{222}$

Tabb cast the issue in terms of the employee's "expectancy interest in the employment contract." He argued that while employees have no justifiable expectation of either continued employment or of just cause for termination, employees expect not to be terminated for a bad faith reason. ${ }^{223} \mathrm{Al}-$

220. A number of commentators have attempted to explain why the much-maligned at-will rule seems impervious to change. For example, Lawrence Blades argues that legislatures are not likely to enact statutes modifying the at-will rule because employees are too diverse and unorganized to form a strong lobby, while employers have strong, organized lobbying groups. Likewise, organized labor has no incentive to change the at-will rule because doing so would essentially give all employees one of the main benefits of a union contract without the need for unions. Blades concludes that any solution must come from the courts. Blades, supra note 172, at 1433-34. On the other hand, Clyde Summers argues that courts are unwilling or unable to break with over one hundred years of precedent, and therefore any solution must be legislative in nature. Summers, supra note 191, at 521.

221. Murray Tabb, Employee Innocence and the Privileges of Power: Reappraisal of Contract Rights, 52 MO. L. REV. 803 (1987).

222. According to Tabb, his "proposed standard does not embrace the extreme position which would jettison the at-will contract in favor of a 'just cause' requirement for dismissal, nor the opposite extreme which would resist inroads or limitations on an employer's freedom to fire employees." Id. at 810-11.

223. Id. at 832 . However, Tabb's terms are not well defined. Tabb simply states that employees "should have a reasonable and protectable expectation not to be unfairly discharged for "bad cause." $I d$. at 832. He does not explain what constitutes bad cause or where to look for a definition. In the absence of a concrete definition, one assumes that Tabb intends to incorporate existing law on the covenant of good faith and fair dealing. Under those principles, bad faith is defined as conduct that deprives the other party of the fruits of the contract. Restatement (Second) of Contracts $§ 205$ (1981); Fortune v. Na- 
though Tabb limits his article to termination, he could make the same argument for other types of employer conduct short of termination if performed in bad faith.

In hindsight, Tabb's focus on the covenant of good faith and fair dealing seems misplaced. Since Tabb's article was published two decades ago, the success of arguments-based good faith and fair dealing claims has proved short-lived. In fact, Tabb's arguments are couched in commendations for specific California cases, most notably Cleary, ${ }^{224}$ which was later overruled. The California Supreme Court effectively eviscerated the covenant of good faith and fair dealing as a general check on employer discretion. Indeed, currently no state applies the covenant of good faith and fair dealing as Tabb advocates. ${ }^{225}$

In states that adhere to the covenant of good faith and fair dealing, courts universally recognize that it is a creature of contract. As such, the covenant arises from and is defined by the contract between the parties. This takes us back to the very concepts that proved limiting in California, specifically intent. The covenant of good faith and fair dealing is intended to "effectuate the intentions of private contracting parties in the performance of their agreement." 226

The courts have held that a violation of the covenant occurs when one party deprives another of the benefits to which the second party is contractually entitled. $^{227}$ Like implied contracts, the covenant of good faith and fair dealing is intended to fill in the gaps left out of the formal contract so that the parties receive the benefits of their intended agreement. The meaning of "good faith" is determined in each case by reference to the contract at issue and the parties' intentions in making that agreement. Ultimately, like implied contract, the covenant of good faith and fair dealing cannot be used

tional Cash Register Co., 364 N.E. 2d 1251, 1257 (Mass. 1977). In other words, bad faith is defined by the terms of the contract itself.

224. Tabb, supra note 221 , at $835-46$.

225. The covenant of good faith and fair dealing is applied differently to employment contracts in different jurisdictions. Some jurisdictions recognize the claim only where the employee is deprived of vested benefits such as already-earned pension or bonus payments. Other jurisdictions require a public policy violation, which renders the claim largely similar to an action for termination in violation of public policy. Some jurisdictions, like California, recognize the existence of the covenant of good faith and fair dealing, but hold that the covenant does not restrict employers' ability to fire employees for any reason. Still other jurisdictions refuse to recognize any covenant of good faith and fair dealing in employment contracts because the concept of bad faith is too amorphous. Id. at 830 (citing case law).

The states other than California that currently recognize some form of claim for the covenant of good faith and fair dealing in the employment relationship are: Alabama, Alaska, Arizona, Arkansas, Connecticut, Delaware, Idaho, Illinois, Indiana, Louisiana, Massachusetts, Nevada, New Hampshire, New Jersey, New York, Oklahoma, Pennsylvania, South Carolina, Vermont, and Wyoming. Kenneth G. Dau-Schmidt, Governance of the Workplace: The Contemporary Regime of Individual Contract, 28 COMP. LAB. L. \& POL. J. 313, 346 \& n.128 (2007).

226. Tabb, supra note 221 , at 831 .

227. Comunale v. Traders \& Gen. Ins. Co., 328 P.2d 198, 200 (Cal. 1958). 
to contradict the explicit terms of the agreement itself. ${ }^{228}$ Therefore, the courts hold that where the clear agreement between the parties is employment at will, the covenant cannot limit employer's ability to terminate employees without good cause. ${ }^{229}$

Tabb tried to sidestep this result by arguing that there is a crucial distinction between good cause and good faith. An employer could fire an employee without cause yet still act in good faith. Only in those situations where there is an element of bad faith (for example, depriving an employee of vested benefits) is an employer's termination without cause actionable. ${ }^{230}$ Therefore, even if the employment contract specifies employment at will (i.e., termination with or without good cause) the covenant of good faith and fair dealing does not necessarily contradict the express terms of the agreement because cause and good faith are two separate issues. Unfortunately, Tabb does not adequately define good faith or explain how it differs from good cause in this context. The example of vested benefits adds nothing because it is a situation that would be prohibited in any case by other rules $^{231}$ or by the more limited conception of the implied covenant of good faith that some states recognize. ${ }^{232}$

In light of the analysis of implied contract, it is not difficult to foresee problems with Tabb's approach. If the covenant of good faith and fair dealing were enforced as Tabb suggests, employers would simply change the express terms of the contract, just as they did after courts began enforcing implied contract claims. After some artful drafting, we would find that employees' good faith and fair dealing claims indeed expressly contradicted the written terms of the agreement.

Tabb proposes in response to this dilemma that the duties of good faith and fair dealing be non-waivable by employers. ${ }^{233}$ However, this fundamentally changes the nature of the remedy. Instead of a doctrine that is intended to effectuate the intent of the parties as evidenced by their agreement, courts would be trying to use the covenant of good faith and fair dealing to import and impose external values on the parties. While this external imposition of values arguably needs to occur, it will only add confusion and the possibility for misapplication if courts resort to a contractbased remedy like the covenant of good faith and fair dealing to achieve this objective. If we want to enforce larger norms or values, we must be

228. See Foley v. Interactive Data Corp., 765 P.2d 373, 400 n.39 (Cal. 1988).

229. Id.

230. See, e.g., id.

231. Employee Retirement Income Security Act (ERISA) §510, 29 U.S.C. § 1140 (2006) (barring termination to deprive employees of their rights to exercise vested benefits such as pensions).

232. See, e.g., Wakefield v. N. Telecom, Inc., 769 F.2d 109, 111 (2d Cir. 1985) (applying N.Y. law) (recognizing implied covenant claims in context of employees fired to deprive them of about-to-vest benefits/commissions); Fortune v. Nat'l Cash Register Co., 364 N.E.2d 1251, 1255-56 (Mass. 1977) (same).

233. Tabb, supra note 221 , at 864 . 
explicit about our intent and logically and doctrinally consistent about what we hope to accomplish and why and how we are going to do it. Only in this way will we be clear in defining the norms or values that we wish to enforce.

\section{b. Relational Contract}

Professor Robert Bird has made a more recent proposal, one that clearly addresses the underlying norms of the employment relationship. ${ }^{.234}$ In a 2005 article, Bird builds on the rich literature on relational contract theory, applying it to the employment setting. ${ }^{235}$ Bird is not the first scholar to apply relational contract principles to the employment setting, ${ }^{236}$ but his article sketches how these principles could be practically implemented by courts.

The foundation of the relational contract approach is that the relationship between an employer and employee consists of much more than just the terms of the contractual arrangement between them. Like any long-term relationship, the employment situation cannot be understood without referencing the collection of established norms and informal relationships that have grown up between the parties. According to Bird, employers and employees often consider these norms more important than legal rules. ${ }^{237} \mathrm{~A}$ court enforcing the relational contract between the parties would enforce these norms, not just the more limited set of express, or even implied, terms typically considered relevant under traditional contract law.

Bird argues that workplace norms are based in part on the "psychological contract" between employers and employees, a concept discussed in greater detail by Katherine Stone. ${ }^{238}$ The psychological contract is not based on a legal model of bargaining and agreement, but a set of expectations about the other party's obligations within the ongoing relationship. ${ }^{239}$

234. Bird, supra note 28.

235. Bird's article builds upon foundational work on relational contract theory by Ian Macneil, Stewart Macaulay, and others. See, e.g., IAN R. MACNEIL, THE NEw SOCIAL CONTRACT (1980); Stewart Macaulay, Non-Contractual Relations in Business: A Preliminary Study, 28 AM. SOC. REv. 55 (1963). Macaulay argues that many businesses primarily look to non-legal and non-contractual mechanisms to structure their business relationships, even when encountering difficulties in those relationships. Customs, practices, and the relationship between the parties fill in contractual holes and keep the relationship running smoothly. Indeed, contract can even have undesirable consequences. See also Stewart Macaulay, Relational Contracts Floating on a Sea of Custom? Thoughts About the ldeas of lan MacNeil and Lisa Berstein, 94 Nw. U. L. REV. 775 (2000).

236. See e.g., Paul J. Gudel, Relational Contract Theory and the Concept of Exchange, 46 BuFF. L. REV. 763, 771-73 (1998) (arguing that voluntarily assumed obligations by an employer have been used by courts to give broader terms to employment contracts).

237. Bird, supra note 28.

238. Katherine V.W. Stone, The New Psychological Contract: Implications of the Changing Workplace for Labor and Employment Law, 48 U.C.L.A. L. REV. 519, 526-71 (2001).

239. Id. at 526-39; Bird, supra note 28 , at 165. 
An employee may perceive that her contributions to the employer (e.g., years of loyal and productive service) create reciprocal obligations on behalf of the employer (e.g., not to demote her arbitrarily). Such an employee may sense the existence of an established psychological contract, even though the employer does not share the same ideas about its terms or even about its existence. ${ }^{240}$ This contract shapes an employee's expectations at work. When the employer breaches it, the employee loses trust and may reduce her commitment to and effort in her work. ${ }^{241}$

Important to this idea of psychological contract is the point that norms can be based on the organizational culture of the employer. ${ }^{242}$ A corporate culture is a set of shared basic assumptions that affect how people behave in a particular workspace and is like the personality of an individual. ${ }^{243} \mathrm{~A}$ firm's organizational culture is predominately shaped by the intentional actions of the employer, particularly its managers and other leaders. ${ }^{244}$ According to Bird, corporate cultures have a profound impact on the relationship between employers and employees, contributing significantly to employees' expectations about how their employer will treat them.

Bird's relational contract theory argues that the law should prohibit "relational opportunism" by the employer. Relational opportunism arises in situations in which the employer is able to secure a benefit by violating the terms of the relational contract. To avoid the possibility of this type of opportunism, Bird urges courts to determine the duties owed by the employer under a relational contract and make them operative. In undertaking this determination courts should examine not only the promises made by the employer through explicit contractual terms, handbook policies, or promises by supervisors, but also the practices of the employer. The rationale for enforcing employer practices is that these practices shape employee expectations just like explicit promises. ${ }^{245}$

Examples of practices which may give content to a relational contract are: 1) rituals that suggest the employer will act a certain way (e.g., continuous training for skills necessary for long term success or allowing employees an opportunity to be heard before discipline); 2) signals regarding workplace conduct (e.g., informal encouragement of employees or statements that the employee is valuable or needed); and 3) symbols (e.g., pro-

240. Stone, supra note 238, at 526-39; Bird, supra note 28 , at 167 .

241. Bird, supra note 28 , at $168-70$.

242. Bird points to a possible third source of workplace norms: corporate codes. A corporate code consists of documents expressing the employer's values and the ethical rules it will follow. Bird states that current research fails to show a strong link between corporate codes and the treatment of employees-corporate codes are generally focused on other concerns. However, Bird notes that further research may reveal such a relationship. Id. at 177-78.

243. Id. at 181 .

244. Id. at 183

245. Id. at 200 
viding a separate elevator and washroom for executives). ${ }^{246}$

Interestingly, Bird argues that courts have already accepted relational principles through the implied contract doctrine, and that his theory of relational opportunism "would represent a natural development of employment law." ${ }^{247}$ In looking at the conduct of the parties in implied contract cases, courts have expressed a willingness to look beyond the four corners of the agreement to enforce the reasonable expectations of the parties. ${ }^{248}$ In effect, Bird argues for a more robust implied contract theory. He believes that courts should enforce employer promises and assurances, but he looks to a broad range of employer action to determine whether such promises or assurances have been made.

Bird's relational contract model is a large step in the right direction. If we want to enforce workplace norms, we should look at the expectations created by the entire relationship between the parties as Bird suggests. However, Bird's ideas remain tied to contractual ideas of intent and contract formation. As the analysis of the California cases on implied contract demonstrates, this is a significant problem where employers typically have neartotal control over the terms of the employment relationship. By referring to the practices and policies of employers, relational contract theory cannot protect employee expectations when an employer attempts to avoid liability through disclaimers or other means.

For Bird's relational contract model to be any more effective than the implied contract model in situations where an employer clearly intends to follow the at-will rule, we would have to do away with the general contract principle that the express terms of an agreement govern. ${ }^{249}$ Relational contract terms are built upon employer actions analogous to the statements, policies, practices, or other non-contractual representations offered in implied contract cases to contradict express written disclaimers.

Assuming that this doctrinal hurdle is overcome and non-express promises are given equal weight in contract interpretation, Bird's relational contract model is still limited. As a contract theory, its focus remains the intent of the parties which is now fleshed out by reference to conduct and express promises. The relational contract model, like traditional contract, seeks merely to enforce what the parties intended for their relationship and is not an easy vehicle for importing outside values or norms into that relationship.

Bird concedes this point when providing some instructive examples of how his relational contract proposal could be implemented:

246. Id. at 200-01.

247. Id. at 205-08.

248. Id.

249. Additionally, Rock and Wachter have argued that norms should not be used by courts because they are difficult to prove, costly to assess and, in any event, are generally self-enforcing. Rock \& Wachter, supra note 39 , at $1932-38$. 
An employee cannot transform a consistently applied arbitrary rule (e.g., no left-handed employees may hold supervisory positions) or malicious workplace practice (e.g., any workers reporting to management of another worker's theft or embezzlement of company property are considered snitches and will be fired) into an actionable wrong just because that employee views that rule as unjust. If an employer chooses to establish such a climate and makes that climate a genuine practice, then the employee should expect the arbitrary treatment as part of the position. ${ }^{250}$

Importantly, the relational contract model leaves the terms of the relational contract in the hands of the employer. Without some structuring provided by broader-based norms, the inquiry remains directed solely at determining the employer's promises and practices to identify the relational contract terms of that particular employment relationship.

As the examples quoted in the excerpt from Bird's article demonstrate, supra, an employer would still be free to structure the relationship in bizarre or unfair ways as long as its policies and practices are internally consistent. Just as the implied contract model, the relational contract model opens the door for employers to avoid any liability other than the at-will default position. While employers may not resort to bizarre extremes, they can restructure their promises and practices to avoid giving workplace norms the force of law and incurring liability.

In fact, adoption of Bird's relational contract model might increase the occurrence of bizarre employer policies and practices by providing a distorted set of incentives. Employers would be rewarded for acting arbitrarily and inconsistently, since such behavior would be less likely to create legally actionable obligations. If, for example, an employer's existing informal practice afforded an opportunity for employees to defend themselves before being disciplined, creation of an enforceable legal obligation to always provide this opportunity for all employees might pressure employers to cease the practice altogether and use more random and idiosyncratic methods, varying employee to employee. Random and idiosyncratic behavior would not constitute a replicable pattern and practice of employment enforceable by courts.

Of course, one could argue that employers receive too many benefits from workplace norms for employers to abandon them at the first hint of litigation. These same arguments were made in the early $1980 \mathrm{~s}$ after courts began enforcing implied contract claims. ${ }^{251}$ While employers made some preliminary attempts to offer progressive employment policies while still holding onto their traditional managerial prerogatives, when the choice between the two became inevitable, employers generally opted for the freedom and flexibility that the at-will scheme provides.

250. Bird, supra note 28 , at 214-15.

251. See, e.g., Coombe, supra note 148. 


\section{Charting Future Directions: Aggregating Expectations and Norms to Govern the Employment Relationship}

Any viable framework for establishing and enforcing workplace norms that bring more balance to the employment relationship must prevent employers from unilaterally defining their own obligations. The recognition of broader-based norms is particularly important in light of the preceding analysis of implied contract doctrine and relational contract theory.

\section{a. Community Norms and Practices}

One way to achieve this objective of enforcing workplace norms is by using the basic tenets of the relational contract model-looking at the totality of the relationship to determine expectations-but with one important difference. We should not only focus on the norms generated within a particular workplace, but also those arising out of a larger community, such as a specific industry or profession. Some relational contract theorists already recognize that parties' expectations are formed in part by industry-based norms and practices, and in part by the agreement and course of conduct between the parties. ${ }^{252}$ I argue that given the unique nature of the employment relationship, industry-based and profession-based norms deserve more recognition than the individual arrangements between the parties. In essence, this is an argument that a particular employer should not be able to "opt out" of a system of workplace norms that are followed by similar employers under similar circumstances.

To some extent, the relatively powerless position of employees and the need to afford employee expectations more weight supports creating an industry-based and/or skilled professional approach. One way to ensure that employee expectations are not unreasonable or frivolous is to anchor them in a larger consensus. Employees are aware of workplace norms that are more general in nature, such as industry-specific or professional expectations for certain categories or classes of employees.

While giving attention to employee expectations, a community norms approach also recognizes that it is important to balance employer needs for efficiency and flexibility. Aggregating employee expectations would help to dispel employer fears of being subjected to irrational or inappropriate requirements. Just as an employee's reasonable workplace expectations are not based solely on the promises and practices of her own employer, an employer's understanding of its responsibility to employees can be shaped by a broader context. Employers respond to this broader context by developing and advertising their competitive practices (e.g., benefits, salary,

252. See, e.g., Stewart Macaulay, Organic Transactions: Contract, Frank Lloyd Wright and the Johnson Building, 1996 WIS. L. REV. 75 (1996). 
workplace environment, leaves) in the marketplace for employees.

In addition to the industry or skilled professional contexts, other nonworkplace-related norms may affect the workplace and exert some influence over employer actions. To go back to Bird's example, even though it is not illegal to prohibit left-handed individuals from becoming supervisors, such a ban would likely result in adverse publicity. Such an action would violate general societal norms, in addition to those of the workplace. Most employees would feel that refusing to promote left-handed people demonstrates improper discrimination. These sorts of broader-based norms shape expectations and arguably should limit employer power within the employment relationship as well.

Workplace norms are not created anew by each individual employer both employers and employees' understanding of workplace norms are based on industry, professional, or even national practices. Because employment norms are larger than any particular workplace, a system seeking to enforce employment norms should look beyond the individual workplace to the source of those norms.

There remains a question of whether individual employers and employees should be able to deviate from general employment standards. Of course, employers should always be free to offer additional job protections not offered by their competitors. The real question is whether and how they should be enforced absent express, clear terms susceptible to contract law. In addition, what should be done with attempts to negotiate lesser protections than these aggregate norms provide? In other words, should aggregate norms be considered a floor below which none could fall even by agreement, or are they merely the default position, thereby supplementing but not eliminating the at-will rule altogether? As my analysis of California law demonstrates, the answer to this question is that aggregate norms must be a floor rather than a default position. Otherwise, employers would have incentive to maneuver around the default rules.

Although it is possible that entire industries or professions would change their behavior in response to the threat of legal liability, thereby eviscerating the aggregate norms, this would be significantly more difficult to achieve. Certainly professional associations would have little incentive to undermine protections for their members. Since this proposal is not for recognition of unfettered employee expectations, but for recognition of those expectations that are reasonable in light of the contexts of an industry or profession, it should not unduly inhibit employer flexibility.

Employers may sometimes have a good reason to deviate from established norms, such as changes in business conditions. Industries would certainly recognize such reasons and respond to the potential for changing business conditions in establishing the standards to be imposed. What would change is the fact that an employer could not deviate from industrywide norms unless that change was generally warranted. Although it is de- 
sirable to have a system flexible enough to accommodate needed change, this flexibility must be equitably balanced against the need to provide fundamental fairness for employees. An aggregate norms system is most likely to achieve this balance.

For example, Professor Katherine Stone argues that the American workplace is changing to a new form of psychological contract. Citing work performed by organizational and management theorists, Stone asserts that employees in the new "digital workplace" no longer expect the stability of a single employer and the protections of the internal labor market. Instead, employees expect to be mobile, and want training that increases their skills and makes them more marketable. ${ }^{253}$ Nonetheless, employees still do not expect employers to act arbitrarily. Even employees who do not expect job security value procedural fairness-that their employers will apply procedures that are consistent, free from bias, based on accurate information, contain a mechanism to correct flawed decisions, and comport with standards of ethics. ${ }^{254}$ If Stone's description of the emerging "digital workplace" accurately describes the norms prevalent in particular industries or professions, the aggregate norms approach would recognize and enforce them. For example, employers could terminate employees without cause if employees had no reasonable expectation to the contrary, based on the totality of the industry's conduct. However, employees might have recourse if employers violated accepted norms of procedural fairness.

It is important to note the limitations of the aggregate norms approach. One might argue that this approach reinforces the hierarchies and power imbalances inherent in workplace norms. For example, it does not ensure that workers are paid a decent wage, or address the continuing problems with de facto racial or gender discrimination in the workplace. However, that is not the goal of the aggregate norms approach. Instead, it is designed to address the particular problem of employer opportunism discussed at Part II.B of this paper-employers taking advantage of employees by fostering a set of expectations regarding job security and then ignoring those protections after receiving the benefits of employees' service. It is limited to enforcing the norms developed in the workplace itself. However, the two projects are not incompatible. Use of the aggregate norms approach to enforce workplace expectations would not preclude parallel efforts to impose outside values on the workplace through legislation or other means. Certainly there are larger issues in the workplace which must be addressed through public policy approaches. Where such public policy considerations are imposed on the workplace, ${ }^{255}$ they should trump workplace norms.

253. STONE, supra note 29 , at $90-114$.

254. Id. at $96-98$.

255. For example, Title VII imposes outside values on the employment relationship by prohibiting discrimination on the basis of race. Title VII of the Civil Rights Act of 1964, 42 U.S.C.A. $\S \S 2000 \mathrm{e}$ to 2000e-17 (West 2008). 


\section{b. Decision-Making}

One potential obstacle in developing and enforcing aggregate norms in the workplace is the courts' lack of familiarity with particular industries or professions. Initially, there might be a flood of cases brought in efforts to clarify the aggregate norms in any industry or profession. While suggesting a detailed system for resolution of aggregate norm cases is beyond the scope of this Article, it is important to note that existing practices, such as mediation and arbitration, offer at least a partial response to these practical problems. ${ }^{256}$

One approach would be to defer decision-making to the industries and professions themselves by establishing panels of experts (including employee representatives). Many industries and professions already have expectations reduced to writing or could easily do so. In addition, the industries and professional associations would be the logical source for decision makers if an arbitration or mediation structure is established for resolution of specific disputes. This type of structure would also help reduce cost and facilitate oversight and enforcement.

Arbitration and mediation have recognized advantages over a courtbased system. They are the dispute resolution mechanisms that most employment contracts specify when that issue is part of contractual determination. These methods of resolution are more flexible than judicial procedures and better able to deal with the diversity in the American workplace. ${ }^{257}$ An associate at a law firm may have a much different set of employment expectations than an employee in a fast food restaurant. If disputes were mediated, an industry-specific panel would be able to apply norms relevant to the particular industry or the type of worker.

In addition, as many commentators have argued, mediation may be less antagonistic than litigation. This allows employers and employees to work out their differences about rights and obligations without polarizing the workplace or effectively ruining the relationship between particular employees and management.

Finally, the cost and expertise advantages of mediation might more easily allow employees to negotiate with their employers and challenge employment decisions other than termination. Not only would the mediation process itself be less cumbersome, but the mediation process would also help identify the established norms in a given industry or profession. These norms could be used in non-litigious negotiation situations between

256. Katherine V.W. Stone, Rustic Justice: Community and Coercion Under the Federal Arbitration Act, 77 N.C. L. REV. 931, 1028-30 (1999) (suggesting that arbitration within a "shared normative community" would be appropriate).

257. Some commentators suggest that arbitration alone might lead to employer creation of a "minimal standard" to avoid the risk that arbitrators might impose more stringent standards. See, e.g., Sid L. Molleo, Birth of a Contract; Arbitration in the Non-Union Workplace, 50 S.C. L. REV. 183, 232-33 (1998). 
individual employees and their employers. ${ }^{258}$

A key factor in the aggregate norms approach to determine the nature of the employment relationship is that it brings into focus, and consequentially affords more weight to, employees' reasonable expectations. Because these expectations are determined by aggregate norms in the various contexts in which they arise, this approach goes beyond the agreements of individuals as in contract law.

Courts presently interpret employees' reasonable expectations based on the terms of the contract and the conduct of the employer. However, as argued supra, employees' expectations often do not match employers' legalistic language, and this allows employers to take advantage of employees. If opportunism in the employment relationship is the problem, then the obvious solution should be to give employees' reasonable expectations more definition and weight in articulating the rules of the employment context.

VII.

\section{CONCLUSION}

Although it may seem somewhat counterintuitive, the enforcement of aggregate norms might actually lead to greater predictability in the workplace. Individual employees and employers would be eager to clarify their specific rights and obligations in relation to more general norms. Assuming employers could not insulate themselves from aggregate norms through contract means, they would have an incentive to create clear, detailed policies consistent with general norms and stick to them.

One example of this dynamic is the process that was set in motion by the enactment of Title VII of the Civil Rights Act of 1964. After the initial wave of discrimination and harassment claims during the 1970s and 1980s, employers created detailed policies regarding discrimination and harassment to avoid liability. These policies not only created clearer expectations for employers as well as employees, but they also defined managers' roles and responsibilities. Many employers established departments to screen and address workplace discrimination and to try to resolve complaints before they deteriorated into lawsuits. ${ }^{259}$ If implemented, the enforcement of

258. Arbitration and mediation are not without problems, of course. For example, arbitration agreements may allow the employer as the more powerful party to manipulate the process. See, e.g., Stewart Macaulay, Freedom from Contract: Solutions in Search of a Problem?, 2004 Wis. L. REV. 777 (2004); Exerpts from Text: EEOC Rejects Mandatory Binding Employment Arbitration, 52 DISP. RES. J. 11,13 (1997).

259. See, e.g., Susan Bisom-Rapp, Fixing Watches with Sledgehammers: The Questionable Embrace of Employee Sexual Harassment Training by the Legal Profession, 24 T.J. L. REV. 125, 133-34 (2002) (discussing adoption of sexual harassment training by employers); Russell J. McEwan \& Margo Eberlein, To Train or Not to Train: Discrimination and Harassment Awareness Training for the Workforce, N.J. LAW. Aug. 2008, at 67 (suggesting that employers establish sexual harassment policies and training to avoid liability). 
aggregate norms has the potential to effectively reverse the trend towards fewer and less detailed written policies that was engendered by the enforcement of implied contract claims. ${ }^{260}$

The use of more generalized aggregate norms, while moving away from contract, might actually result in establishing workplace conditions that are more conducive to bargaining and negotiation. The labor market might begin to look like a field in which employees can bargain more effectively than has been the case under the at-will rule, which conferred upon the employer most of the bargaining chips. If industry or profession-wide norms push employers towards more specificity and greater transparency, it would become easier for employees to assess one workplace against another. Enforcing employee expectations through the aggregate norms approach will allow the process of negotiation to flourish, resulting in workplace protections and policies that are the products of both competition and compromise.

260. It is important to note the controversy surrounding Title VII's effects on employer policies Some scholars argue that the creation of detailed policies protects employers from liability without adequately furthering Title VII's policy of eradicating discrimination on the basis of sex. E.g., BisomRapp, supra note 259 , at $142-44$. 